\title{
Thunderstorms and upper troposphere chemistry during the early stages of the 2006 North American Monsoon
}

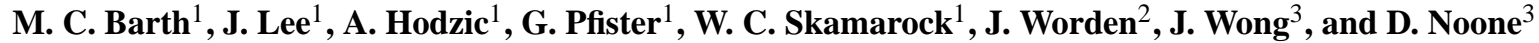 \\ ${ }^{1}$ National Center for Atmospheric Research, Boulder, Colorado, USA \\ ${ }^{2}$ Jet Propulsion Laboratory, California Institute of Technology, Pasadena, California, USA \\ ${ }^{3}$ Department of Atmospheric and Oceanic Sciences and Cooperative Institute for Research in Environmental Sciences, \\ University of Colorado, Boulder, Colorado, USA
}

Correspondence to: M. C. Barth (barthm@ucar.edu)

Received: 4 June 2012 - Published in Atmos. Chem. Phys. Discuss.: 4 July 2012

Revised: 26 October 2012 - Accepted: 9 November 2012 - Published: 21 November 2012

\begin{abstract}
To study the meteorology and chemistry that is associated with the early stages of the North American Monsoon, the Weather Research and Forecasting model coupled with Chemistry (WRF-Chem) is applied for the first time at high resolution ( $4 \mathrm{~km}$ grid spacing, allowing for explicit representation of convection) over a large region (continental US and northern Mexico) for a multi-week (15 July to $7 \mathrm{Au}-$ gust 2006) integration. Evaluation of model results shows that WRF-Chem reasonably represents the large-scale meteorology and strong convective storms, but tends to overestimate weak convection. In the upper troposphere, the WRFChem model predicts ozone $\left(\mathrm{O}_{3}\right)$ and carbon monoxide $(\mathrm{CO})$ to within $10-20 \%$ of aircraft and sonde measurements. Comparison of $\mathrm{UT}_{3}$ and $\mathrm{CO}$ frequency distributions between WRF-Chem and satellite data indicates that WRF-Chem is lofting $\mathrm{CO}$ too frequently from the boundary layer (BL). This excessive lofting should also cause biases in the WRFChem ozone frequency distribution; however it agrees well with satellite data suggesting that either the chemical production of $\mathrm{O}_{3}$ in the model is overpredicted or there is too much stratosphere to troposphere transport in the model. Analysis of different geographic regions (West Coast, Rocky Mountains, Central Plains, Midwest, and Gulf Coast) reveals that much of the convective transport occurs in the Rocky Mountains, while much of the UT ozone chemical production occurs over the Gulf Coast and Midwest regions where both $\mathrm{CO}$ and volatile organic compounds (VOCs) are abundant in the upper troposphere and promote the production of peroxy radicals. In all regions most of the ozone chemical production occurs within $24 \mathrm{~h}$ of the air being lofted from the boundary
\end{abstract}

layer. In addition, analysis of the anticyclone and adjacent air indicates that ozone mixing ratios within the anticyclone region associated with the North American Monsoon and just outside the anticyclone are similar. Increases of $\mathrm{O}_{3}$ within the anticyclone are strongly coincident with entrainment of stratospheric air into the anticyclone, but also are from in situ $\mathrm{O}_{3}$ chemical production. In situ $\mathrm{O}_{3}$ production is up to $17 \%$ greater within the anticyclone than just outside the anticyclone when the anticyclone is over the southern US indicating that the enhancement of $\mathrm{O}_{3}$ is most pronounced over regions with abundant VOCs.

\section{Introduction}

Convection transports chemical constituents from the boundary layer to the upper troposphere (Chatfield and Crutzen, 1984; Dickerson et al., 1987), where these chemical species undergo long-range transport and have increased lifetimes due to the cold temperatures. The global-scale impact of deep convection on the upper troposphere (UT) composition has been estimated using 3-dimensional, global-scale chemistry transport models (Lelieveld and Crutzen, 1994; Lawrence et al., 2003), which show that upper tropospheric ozone $\left(\mathrm{O}_{3}\right)$ can be locally enhanced by upward transport in convection over polluted regions. Lawrence et al. (2003) found that the net global effect of convective transport of $\mathrm{O}_{3}$ and its precursors is to increase the amount of $\mathrm{UT}_{3}$ by $12 \%$. While these estimates on the importance of deep convection and $\mathrm{O}_{3}$ provide an important context for convection and chemistry 
studies, they are based on results from models with coarse resolution and parameterized convection. As these parameterizations are highly idealized representations of convective processes, there are substantial uncertainties in the global estimates of gas and aerosol transport by convection.

Park et al. (2004) investigated the role of convection on $\mathrm{O}_{3}$ and carbon monoxide (CO) and on the impact of their intercontinental transport. The importance of adequately resolving mesoscale flow features for the purpose of quantifying convective transport was illustrated by contrasting simulation results produced using a uniform computation grid of $2.0^{\circ}$ longitude $\times 2.5^{\circ}$ latitude to results produced using a "stretched grid" with a $0.5^{\circ}$ longitude $\times 0.5^{\circ}$ latitude mesh over the central US where convection is occurring. Their results showed $\mathrm{O}_{3}$ production rates to be nearly 3 times greater over eastern North America at a $10.6 \mathrm{~km}$ altitude two days after convection occurred in the central US in the lower resolution simulations $\left(2.0^{\circ} \times 2.5^{\circ}\right)$ than in the stretched grid simulations $\left(0.5^{\circ} \times 0.5^{\circ}\right)$ because of the more rapid dilution of the convective outflow plume. Thus, adequate representation of the mesoscale features is required to accurately account for convective transport. While the Park et al. (2004) study indicates that thunderstorms and chemistry are responsible for increased ozone in the UT, they do not point to specific geographic regions that may be affecting the UT ozone chemistry more than other regions. In this paper, we analyze results from the Weather Research and Forecasting (WRF) model coupled with Chemistry (WRF-Chem) to determine which geographic regions contribute to convective transport and to $\mathrm{O}_{3}$ production in UT convective outflow regions.

Recent papers (Zhang et al., 2003; Li et al., 2005; Cooper et al., 2006, 2007, 2009) have documented the existence of an enhancement in upper troposphere ozone during July and/or August. For example, observations (interpolated from ozonesondes and Measurement of OZone and water vapour by Airbus In-service Aircraft (MOZAIC) data during August 2006) show an UT $\mathrm{O}_{3}$ enhancement over the southeast US (Cooper et al., 2007). The enhanced $\mathrm{O}_{3}$ in the UT is a recurring event (Cooper et al., 2007) and is related to the anticyclone that sets up during the North American Monsoon (NAM), a seasonal shift in winds that allows low level moisture to flow into the southwest US from the Gulfs of California and Mexico. The low level moisture combined with increased UT water vapor flowing northwards along the Rocky Mountains from the Gulf of Mexico and Pacific Ocean provides ample moisture to sustain deep convection associated with the NAM. The enhanced $\mathrm{O}_{3}$ in the UT is also found in satellite data (A. M. Eldering, personal communication, 2011) and in several modeling studies (Zhang et al., 2003; Li et al., 2005; Choi et al., 2009).

It is hypothesized that the enhanced UT ozone is a result of thunderstorms and chemistry occurring during the North American Monsoon when the UT anticyclone traps the air (Li et al., 2005; Cooper et al., 2007). Thunderstorms transport boundary layer air that is rich in volatile organic com- pounds (VOCs) and are a source for lightning-produced nitrogen oxides $\left(\mathrm{NO}_{\mathrm{x}}\right)$. Both VOCs and $\mathrm{NO}_{\mathrm{x}}$ along with solar radiation are ingredients for producing $\mathrm{O}_{3}$. Lagrangian model simulations of a lightning- $\mathrm{NO}_{\mathrm{x}}$ tracer show that the locations of chemically produced $\mathrm{UT} \mathrm{O}_{3}$ would primarily occur in the southern US (Cooper et al., 2009). In addition to a local chemical source of $\mathrm{O}_{3}$, high $\mathrm{O}_{3}$ mixing ratios could be a result of transport of $\mathrm{O}_{3}$ from the stratosphere to the UT. Simulations using the GEOS-Chem model indicate that, when the stratospheric $\mathrm{O}_{3}$ is well simulated, the agreement between model results and ozonesondes is within $10 \%$ in the UT (Jourdain et al., 2010), indicating that stratospheric $\mathrm{O}_{3}$ may be contributing to $\mathrm{UT}_{3}$ mixing ratios.

In these previous model studies and others (Allen et al., 2010, 2012; Zhao et al., 2009), the ability to represent the convection was limited because the models' horizontal grid spacing was too coarse to resolve convective transport. In these studies, convective parameterizations were used to represent the convective transport. Our WRF-Chem simulations are configured at $4 \mathrm{~km}$ grid spacing so that convective systems and convective transport are explicitly simulated. After evaluating the results of our simulation using both meteorological and chemical observation data, the WRF-Chem model results are analyzed to examine regions of the US that contribute to the UT $\mathrm{CO}$ and $\mathrm{O}_{3}$ mass. In addition to identifying geographic regions of importance for convective transport and subsequent $\mathrm{O}_{3}$ production in the UT convective outflow, the role of the anticyclone associated with the North American Monsoon on these constituents and their chemistry is examined. In particular, the contribution of in situ $\mathrm{O}_{3}$ production and stratospheric intrusions to elevated $\mathrm{O}_{3}$ mixing ratios within the anticyclone are discussed.

\section{Model description}

The Weather Research and Forecasting model (Skamarock et al., 2008) coupled with Chemistry (Grell et al., 2005; Fast et al., 2006) version 3.0.1 is used to simulate the meteorology and chemistry over the US and Mexico (Fig. 1) from 00:00 UTC 10 July to 00:00 UTC 7 August 2006. There are $1200 \times 900$ grid points in the west-east and south-north directions, respectively, for the $4 \mathrm{~km}$ horizontal grid spacing domain. The vertical coordinate has 51 levels from the surface to $10 \mathrm{hPa}$. The vertical grid spacing near the surface is $\sim 60 \mathrm{~m}$, for $1-3 \mathrm{~km}$ altitudes it is $200-400 \mathrm{~m}$, and for $5-$ $13 \mathrm{~km}$ it is $540-600 \mathrm{~m}$.

\subsection{Meteorology}

Two coarse-scale WRF outer domains $(36 \mathrm{~km}$ and $12 \mathrm{~km}$ grid spacing, respectively) are used to downscale the NCEP Global Forecast System (GFS) Final Analyses $\left(1^{\circ} \times 1^{\circ}\right.$ grid spacing) to the US and Mexico $4 \mathrm{~km}$ grid spacing domain shown in Fig. 1. The two outer domains, which have 


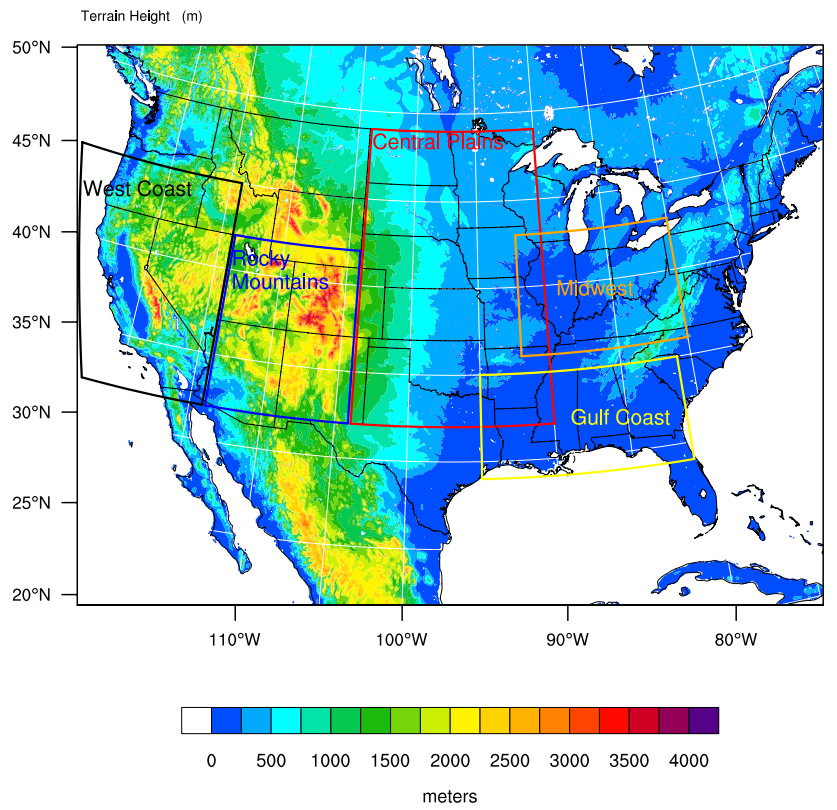

Fig. 1. Domain and terrain height (m) of the model simulation. Marked regions are used in the radar reflectivity evaluation and the chemistry analysis.

southwest-northeast latitudes and longitudes of $13.0-53^{\circ} \mathrm{N}$, $123-53^{\circ} \mathrm{W}$ for the $12 \mathrm{~km}$ domain and $2-56^{\circ} \mathrm{N}, 129-28^{\circ} \mathrm{W}$ for the $36 \mathrm{~km}$ domain, are run for meteorology only over a two month period using two-way nesting. The two outer domains are re-initialized from NCEP meteorology approximately every week to avoid excessive drift away from observations. The results of the $12 \mathrm{~km}$ grid spacing domain are then used for one-way nesting onto the US and Mexico domain. For the innermost $4 \mathrm{~km}$ domain, the meteorology is nudged every $6 \mathrm{~h}$ to GFS analysis of temperature above the boundary layer and of horizontal winds throughout the model domain so that large-scale features maintain a position consistent with observations. Because the two outer domains are re-initialized approximately every week, the WRFChem simulation over the $4 \mathrm{~km}$ domain is also re-initialized for the meteorology at the same time. The chemistry is not re-initialized, but instead is continued from the previous run.

The prognostic meteorology parameters including winds, potential temperature, pressure, water vapor, and condensed water (i.e., cloud particles), tracer variables, and chemistry species are integrated forward in time using a Runge-Kutta integration method. The moisture variables, scalars, and chemistry species are advected using a monotonic scheme (Wang et al., 2009).

Cloud physics are computed with the Lin et al. (1983) single moment parameterization. This scheme predicts water vapor, cloud water, rain, cloud ice, snow, and graupel. No convective parameterization is used on the $4 \mathrm{~km}$ grid. The planetary boundary layer parameterization used in the simulation is the Mellor-Yamada-Janjic scheme (Janjic, 2002).
At the surface, the NOAH land surface model (Chen and Dudhia, 2001) is employed. For heating rates, the Goddard scheme (Chou and Suarez, 1994) is used for short wave radiation and the Rapid Radiative Transfer Model (Mlawer et al., 1997) is used for long wave radiation. In the US and Mexico domain, we allow the predicted aerosol distributions to affect the radiation calculation and the cloud physics using the modifications described by Chapman et al. (2009) to accommodate aerosol effects on cloud drop activation.

\subsection{Chemistry}

The initial and boundary conditions for the chemistry species come from 6-hourly output of the CAM-Chem model, which was run at a $2.5^{\circ} \times 1.9^{\circ}$ resolution. At this resolution, the CAM-Chem model is able to simulate plumes from anthropogenic and biomass burning sources that originate in Asia and are transported to North America. Species taken from the CAM-Chem simulation include intermediate and long-lived gases (radicals such as $\mathrm{OH}$ and $\mathrm{HO}_{2}$ are not included), dust, sea salt, and primary and secondary particulate organic carbon. Sulfate and nitrate aerosols are not included in the initial and boundary conditions. The boundary conditions are applied from the surface to the top of the model $(p=10 \mathrm{hPa}$ which is $\sim 30 \mathrm{~km}$ altitude) such that stratospheric $\mathrm{O}_{3}$ in WRF-Chem is provided by the CAM-Chem boundary conditions. In addition, the 25 July-7 August segment of the WRFChem simulation has an imposed upper boundary condition following Lamarque et al. (2012). A comparison of the WRFChem results with and without the chemical upper boundary condition gives the same values for $\mathrm{CO}$ and $\mathrm{O}_{3}$ below $14 \mathrm{~km}$ altitude where the analysis in this paper is focused.

The gas-phase chemistry mechanism used for the simulation is the RACM mechanism (Stockwell et al., 1997). A kinetic pre-processor (KPP) and Rosenbrock solver (Sandu et al., 2006) is used to solve the stiff set of gas phase chemical reactions. The MADE/SORGAM (Ackermann et al., 1998) modal approach is employed for the aerosols. Two modes (Aitken and accumulation) are solved for the following aerosol species: sulfate, nitrate, ammonium, sodium, chloride, sea salt, soil (dust), primary organic carbon, and secondary organic carbon. Dust emissions (Shaw et al., 2008) are included by assuming the dust flux $\left(\mathrm{kg} \mathrm{m}^{-2} \mathrm{~s}^{-1}\right)$ to be $1 \times 10^{-14} \times U_{*}^{3.5}$ where $U_{*}$ is the friction velocity. Dust emissions are also a function of the landuse type. The inorganic chemistry system is based on MARS (Saxena et al., 1986) and includes modifications suggested by Binkowski and Shankar (1995), which uses equilibrium thermodynamics to calculate the chemical composition of a sulphate/nitrate/ammonium/water aerosol.

Several emission sources are included in the simulations. The anthropogenic emissions come from the US EPA National Emission Inventory (NEI) representative of 2005 typical summertime weekday (S. McKeen, personal communication, 2010) and from the Mexico NEI representative of 
1999 emissions as used by Fast et al. (2009) and Hodzic et al. (2010). These emissions are reduced for Saturdays and Sundays following the findings of Stephens et al. (2008). The Saturday emissions are $75 \%, 90 \%, 90 \%$, and $93 \%$ of weekday emissions for $\mathrm{NO}, \mathrm{CO}$, VOCs, and $\mathrm{BC}$, respectively. The Sunday emissions are $60 \%, 75 \%, 75 \%$, and $80 \%$ of weekday emissions, for NO, CO, VOCs, and BC, respectively. Biogenic emissions are calculated online with the Model of Emissions of Gases and Aerosols from Nature (MEGAN) model (Guenther et al., 2006), which uses WRFpredicted temperature and downward radiation for its calculations. Wildfire emissions are based on fire locations as seen by the MODIS sensors aboard the NASA Terra and Aqua satellites (Wiedinmyer et al., 2006). The injection height of the wildfire emissions is computed using a plume-rise module (Freitas et al., 2005, 2011). Aircraft emissions of CO, $\mathrm{NO}$, and $\mathrm{SO}_{2}$ from scheduled, charter, general aviation and military traffic for 1999 are included at a $1^{\circ} \times 1^{\circ}$ resolution (Baughcum et al., 1996, 1998; Mortlock and Alstyne, 1998; Sutkus et al., 2001).

The photolysis rates are calculated using fast-TUV (Tie et al., 2003) which adjusts the rate according to the presence of aerosols and/or clouds in the grid cell. In determining the photolysis rates, the overhead $\mathrm{O}_{3}$ column is set to 300 Dobson units over the US and 280 Dobson units over Mexico. Dry deposition of gases and aerosols follow the Wesely (1989) resistance method. Wet deposition of soluble gases and aerosols is calculated as described by Easter et al. (2004).

The production of NO from lightning has been implemented in this simulation. The number of lightning flashes is computed based on the maximum updraft speed (Price and Rind, 1992) within each parallel-processing tile $\left(200 \times 116 \mathrm{~km}^{2}\right.$ region $)$ of the domain. The predicted flash rate is not adjusted from the original equation and underpredicts the cloud-to-ground lightning flash rate observed by the National Lightning Detection Network (NLDN) by up to an order of magnitude (Wong et al., 2012). The intracloud to cloud-to-ground flash ratio is based on climatology (Boccippio et al., 2001), which shows high ratios (>3) for the region between $105^{\circ} \mathrm{W}$ and $90^{\circ} \mathrm{W}$ and lower ratios elsewhere. The NO source from lightning is placed within the $20 \mathrm{dBZ}$ volume of the storm, following the vertical distribution curves given by DeCaria et al. (2005). For both intra-cloud and cloud-to-ground flashes, 330 moles of NO are produced per flash. Included in the simulation are two passive lightning $\mathrm{NO}_{\mathrm{x}}$ tracers, one tracing $\mathrm{NO}_{\mathrm{x}}$ produced from cloud-to-ground flashes and the second tracing $\mathrm{NO}_{\mathrm{x}}$ from intracloud flashes. Both tracers have the same source strength determined from the lightning- $\mathrm{NO}_{\mathrm{x}}$ parameterization, but then are only transported in the model domain; there are no sinks for these two tracers.

\subsection{Tracers and other diagnostic parameters}

By including tracers and diagnostic parameters, the analysis of the processes occurring in the simulation can be made without altering the results of the simulation. Emmons et al. (2012) note that there are deficiencies in the analysis when emissions are reduced or removed in a specified region to determine the source attribution for ozone because of the nonlinearity of the ozone chemistry. In our simulation there is the concern that changes in the chemistry could lead to a different meteorological scenario because the simulation allows feedbacks between the chemistry and meteorology through radiation and cloud physics. With these meteorology changes, it would be difficult to attribute the ozone to the intended change or to the other changes in the simulation. We include tracers representing boundary layer air, stratospheric air, and lightning $\mathrm{NO}_{\mathrm{x}}$ emissions (as described above). Diagnostic parameters are also included to track the chemical net production and advection tendency of $\mathrm{CO}$ and $\mathrm{O}_{3}$.

To track boundary layer air, stratospheric air, and air from the horizontal boundaries, six tracers are included. The boundary layer tracers are defined as having a value of one from the surface to the planetary boundary layer (PBL) height. These tracers are maintained at the value of one in this region throughout the simulation. The stratosphere tracers are defined as having a value of one from the height of the tropopause to the top of the domain $(10 \mathrm{hPa})$. Initially, for the 10-24 July segment of the simulation, the tropopause is defined as the height of the minimum temperature, which may misrepresent the actual tropopause especially when a double tropopause is present. To use a better diagnostic, the WMO definition of the tropopause is used for the 25 July-7 August segment of the simulation. These tracers also retain this value of one within the stratosphere. The horizontal boundary tracers are initially set to zero within the model domain. Their value at the horizontal boundaries is set to one throughout the simulation. Thus, the horizontal boundary tracer allows us to track air that has originated outside the model domain.

Two types of tracers are used. A non-decaying tracer $\left(c_{0}\right)$ is only transported, while its twin tracer $(c)$ decays with a time scale of one day. The decaying tracer loss term is

$$
\frac{\mathrm{d} c}{\mathrm{~d} t}=-k c
$$

where $k$ is the decay rate of 1 day $^{-1}$. By taking the logarithm of the ratio of the decaying tracer to the passive tracer, the age of air for the tracer can be estimated. Specifically, upon integrating Eq. (1), the age is defined as

$$
t_{\mathrm{age}}=\frac{1}{k} \ln \left(\frac{c}{c_{0}}\right)
$$

Estimating the age of air using this method gives an idea of how long it has been since the air parcel has been lofted from the boundary layer. However, it is quite possible erroneous 
ages are calculated when mixing of fresh and older air occurs.

Two wildfire tracers, one passive and one with a one-day first-order decay rate, are included to follow air influenced by wildfire emissions. The wildfire tracers have an emission source strength that is the same as the $\mathrm{CO}$ emissions from the wildfires. As with the other tracers, there are no physical sinks (e.g. dry or wet deposition) for the wildfire tracers.

Diagnostics for $\mathrm{CO}$ and $\mathrm{O}_{3}$ tendencies are included in the model calculation. These tendencies include the change in the $\mathrm{CO}$ or $\mathrm{O}_{3}$ mixing ratio from advection (in all 3 directions), from the vertical mixing, from horizontal mixing, and from chemistry. These diagnostics are assigned the tendency term in the case of advection and mixing, and are calculated as the difference of the species mixing ratio before and after the chemistry solver.

\section{Description of chemistry data used for model evaluation}

WRF-Chem $\mathrm{CO}$ and $\mathrm{O}_{3}$ results are evaluated with observations from the Tropospheric Emission Spectrometer (TES) instrument onboard the AURA satellite, ozonesondes, and MOZAIC profiles. The TES instrument is an infrared Fourier transform spectrometer (FTS), which measures spectral infrared (IR) radiances between $650 \mathrm{~cm}^{-1}$ and $3050 \mathrm{~cm}^{-1}$ in a limb viewing and a nadir (downward-looking) mode. The technique has a horizontal footprint of $5.3 \mathrm{~km}$ by $8.4 \mathrm{~km}$ in the nadir view, which provides vertical information of the measured species (e.g., Worden et al., 2004 and references therein). Under cloud-free conditions, TES is sensitive to both lower and upper tropospheric ozone with a vertical resolution between $6-8 \mathrm{~km}$. TES is sensitive to CO in the middle and upper troposphere under nominal clear-sky conditions (Worden et al., 2004). The data used here were taken in the "step-and-stare" mode, in which observations are taken every $25 \mathrm{~km}$ over an arc of 60 degrees. To compare WRF-Chem results with the TES measurements, the model results are modified following the same procedure used in the satellite retrieval algorithm. The procedure applies the TES a priori data and averaging kernel, which designates the vertical sensitivity of the retrieval, and then removes results for regions where cloud interference was found.

Ozonesondes are launched from Trinidad Head, CA, Boulder, $\mathrm{CO}$, and Huntsville, AL representing three different regions of the conterminous US. During July 2006, these balloons were launched approximately weekly and in August 2006 the balloons were launched daily as part of the special observations for the Texas Air Quality Study (Cooper et al., 2007; Thompson et al., 2008). Between 15 July and 6 August, there were 8 balloons launched at each of the locations. The data from each of these sites were averaged and standard deviations calculated. The WRF-Chem profiles were obtained, first, by averaging model result profiles over a $48 \times 48 \mathrm{~km}^{2}$ area (a region that is small enough to have somewhat homogeneous ozone mixing ratios, yet large enough to account for deviations caused by poorly-predicted small-scale meteorology) centered on the grid point that is nearest the ozone launch site. These average profiles were obtained for each of the observed times. Then, like the observations, these profiles from different days for each location were time-averaged and standard deviations calculated.

During the 15 July to 3 August 2006 period, there were 46 profiles of MOZAIC data (Marenco et al., 1998) available within the WRF-Chem domain. Many of these profiles occurred for takeoffs and landings in Atlanta, GA, Dallas, TX, and Portland, OR. As with the ozonesonde data, the MOZAIC $\mathrm{O}_{3}$ and $\mathrm{CO}$ profiles were averaged and standard deviations calculated for each location. The WRF-Chem profiles were constructed by finding the nearest model grid cell to each of the MOZAIC data points. The profiles were then averaged for each of the locations and standard deviations were calculated.

\section{Results}

We have performed a WRF-Chem model simulation from 10 July to 7 August 2006, for which the 15 July to 7 August period has been analyzed to avoid the influence of the model spin up during the first few days. This time period was selected to examine the transition from a relatively unperturbed upper troposphere with respect to ozone mixing ratios to the onset of the anticyclone over the southern US. Thunderstorms were occurring daily over the western Rockies and along the Gulf Coast during this period. We define four meteorological periods during the simulation to examine the composition and chemistry of the upper troposphere in relation to thunderstorm activity. Figure 2 (left panels) shows the ECMWF Interim Reanalysis (ERA-Interim) of the $300 \mathrm{hPa}$ geopotential heights for one day from each of the four meteorological periods. From 15-17 July 2006 (period 1) the northern Great Plains of the US began to experience heat wave conditions. This region was located below an anticyclone (marked by the geopotential height of $\sim 9800 \mathrm{~m}$ ) that was present at both 500 and $300 \mathrm{hPa}$. The anticyclone migrated westward and was over the western US from 18 25 July (period 2) when California experienced anomalously high temperatures. Due to a cold front that traveled from the Great Lakes region to the Gulf of Mexico on 21-22 July, the anticyclone remained over the western US for a full week. From 26 to 31 July (period 3) the anticyclone moved eastward, once again creating heat wave conditions over the Central Plains of the US The anticyclone continued to move eastward and was located over the southeast and south-central region of the US from 1-7 August 2006 (period 4). 


\subsection{Evaluation of the predicted meteorology}

To evaluate the WRF-Chem results, four specific dates, 18 July, 23 July, 27 July, and 1 August, at 00:00 UTC are used to illustrate how well the modeled variables compare with observations or ERA-Interim analysis. In the comparison of the $300 \mathrm{hPa}$ heights from the WRF simulation with the ERA-Interim analysis, it is apparent that the simulation predicts the location and magnitude of the geopotential heights (Fig. 2) fairly well. The ERA 2-m temperature maps (not shown) have regions of high temperatures $\left(>310 \mathrm{~K}\right.$ or $\left.37^{\circ} \mathrm{C}\right)$ coincident with the high $300 \mathrm{hPa}$ heights. During the early period of the simulation, temperatures are high over the Central Plains. These high temperatures are seen primarily over the west on the 23 July and then move eastward late in July. The WRF simulation largely reproduces these patterns although some regional differences in temperatures exist.

Deep convection occurred throughout the time period of the simulation. The WSI (Weather Services International) radar composites (i.e. maximum reflectivity in a column) from the National Weather Service radar network show scattered convection over the Rocky Mountain region (Fig. 3), and often show frontal or deep convective systems occurring in the Central Plains or eastern US. The model-derived composite radar reflectivity captures these main features. Early in the simulation period on 18 July at 00:00 UTC (which corresponds to 05:00 p.m. local time on the West Coast and 08:00 p.m. local time on the East Coast), both the observations and model results show (Fig. 3a,b) scattered convection over the Rocky Mountain States (Utah, Colorado, Arizona, New Mexico) and more organized convection extending from Iowa to Lake Huron. There is also convection occurring in a region extending from Alabama to Florida that WRF places in Georgia. The radar reflectivity on 23 July (Fig. 3c, d) shows a cold front extending from North Carolina along the Gulf Coast and into western Texas. The WRF simulation also depicts this cold front but its location is further north than the observations in Texas and it extends further west. On 27 July the deep convection occurred in a mostly non-organized fashion over most of the US (Fig. 3e, f). The WRF results also show a lot of small unorganized, scattered convection, but are not in good agreement with observations. Because WRF is configured with a $4 \mathrm{~km}$ grid spacing without a convective parameterization, scattered convection, with narrow updrafts, is not expected to be represented well. It is expected that the small unorganized, scattered convection would be better predicted with either a finer grid spacing (e.g. $1 \mathrm{~km}$ ) or with inclusion of a convective parameterization that is able to represent upward mass flux at the grid cell and downward mass flux at neighboring grid cells. On 1 August a cold front with deep convection extended from Lake Superior to New Mexico (Fig. 3g, h). The WRF results show a similar cold front, but with more numerous convective cells. In summary, the WRF simulation at a grid spacing of $4 \mathrm{~km}$ generally reproduces the organized deep convective systems although the location of the individual storm cells is not always accurately predicted. In addition, WRF does not reproduce well the weakly organized convection.

While comparing maps of these results is a qualitative comparison, it gives insight as to how well WRF is representing the large-scale meteorology. We further analyze the reflectivity results quantitatively by comparing radarreflectivity frequency distributions for four different regions, the Rocky Mountains, the Gulf Coast, the Central Plains, and the Midwest. These four regions are marked in Fig. 1. The frequency distributions are calculated at 8 different times of the day so that the diurnal variation can be discerned. The frequency distributions (Fig. 4) determined from the NWS radar reflectivity indicate a strong diurnal cycle over the Rocky Mountains and over the Gulf Coast with peak convection occurring at 00:00-03:00 UTC for the Rocky Mountains and 21:00-00:00 UTC for the Gulf Coast. Generally the frequency distributions from the observations peak near $20 \mathrm{dBZ}$ for all four regions. The frequency distributions from the WRF simulations also have the strongest diurnal variation for the Rocky Mountains and Gulf Coast regions, but peak convection occurs at 21:00-00:00 UTC in the simulation for the Rocky Mountains and 18:00-21:00 UTC for the Gulf Coast, i.e., $3 \mathrm{~h}$ earlier than observations. Unlike the observations, the WRF results have a peak occurring at $<10 \mathrm{dBZ}$ and then a second peak at $30-35 \mathrm{dBZ}$, where this second peak is of similar magnitude as the observed frequency of 30-35 dBZ. Realizing that convective transport will be less important for storms with reflectivity $<20 \mathrm{dBZ}$, we can limit the evaluation to radar reflectivity $>20 \mathrm{dBZ}$. Thus, we find that the frequency of deep convection is overpredicted in the Rocky Mountain region for reflectivity $>30 \mathrm{dBZ}$ and underpredicted along the Gulf Coast for reflectivity $>30 \mathrm{dBZ}$, but has similar frequencies of distribution for the Central Plains and Midwest. These discrepancies are in part related to the choice of the Lin et al. (1983) microphysics scheme, which is known to create intense convective cells and weaker stratiform regions (Seifert and Weisman, 2005) because of the assumptions for producing hail. In terms of convective transport of chemical species from the PBL to the UT, it is likely that the convective transport is too large over the Rockies (where the boundary layer air ranges from fairly clean to more polluted near cities) and too small over the Gulf Coast region (where the boundary layer air is more polluted).

\subsection{Predicted $\mathrm{O}_{3}$ and $\mathrm{CO}$ in the upper troposphere}

\subsubsection{Spatial patterns}

The modeled $\mathrm{O}_{3}$ and $\mathrm{CO}$ at $300 \mathrm{hPa}(\sim 9.8 \mathrm{~km}$ altitude) is averaged for each meteorological time period during the NAM simulation (Fig. 5). During the 15-17 July period when the anticyclone was situated over the Central Plains, low values of UT O 3 (Fig. 5a) are found over the western US. These low $\mathrm{O}_{3}$ values are not associated with active deep convection but 


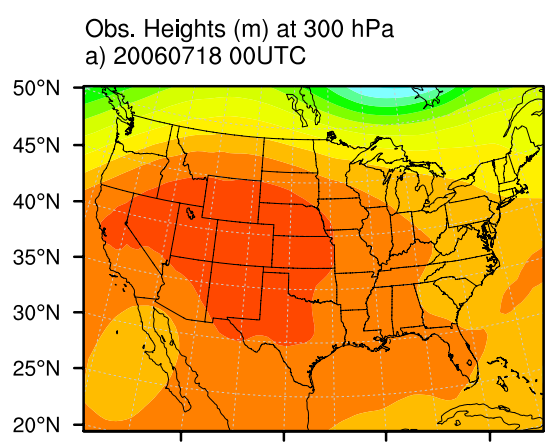

c) 20060723 00UTC

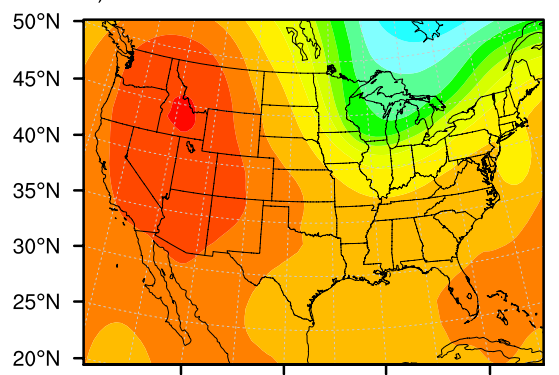

e) 20060727 OOUTC

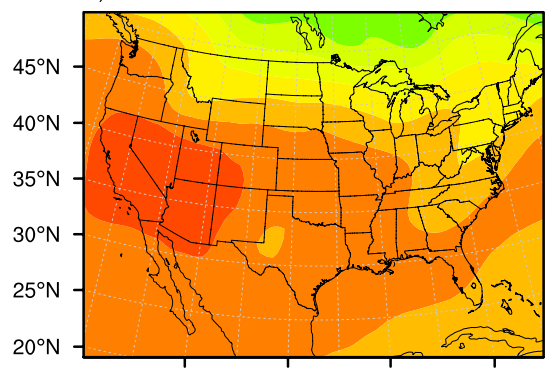

g) 20060801 00UTC

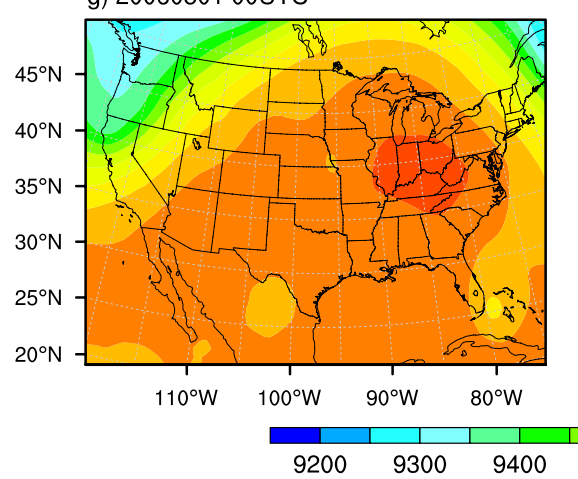

WRF Heights (m) at $300 \mathrm{hPa}$

b) 20060718 00UTC

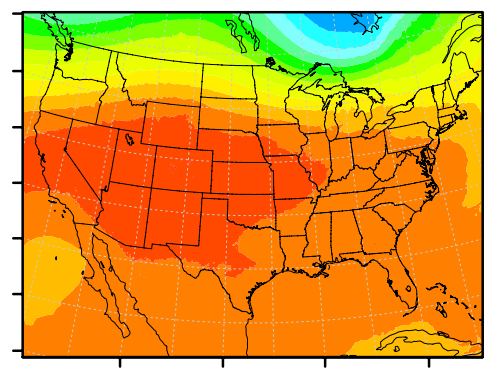

d) 20060723 00UTC

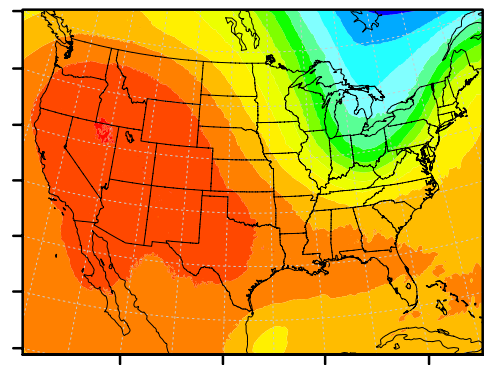

f) 20060727 00UTC

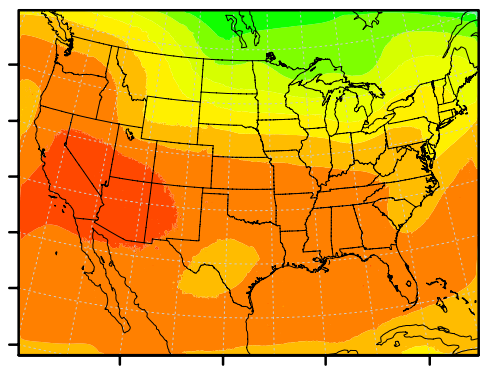

h) 20060801 00UTC

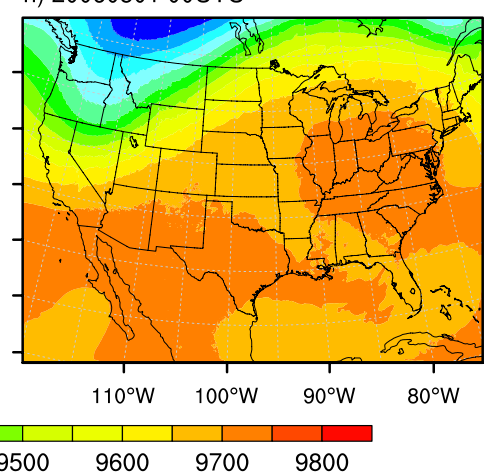

Fig. 2. Spatial distribution of $300 \mathrm{hPa}$ geopotential heights $(\mathrm{m})$ from the ECMWF ERA-Interim reanalysis (left panels) and WRF-Chem model results (right panels) at 00:00 UTC for 18 July 2006 (a, b), 23 July 2006 (c, d), 27 July 2006 (e, f), and 01 August 2006 (g, h).

are still correlated with the boundary layer tracer. While the western US is susceptible to inflow from the boundary conditions, examination of model results before 15 July show convection and convective transport of high $\mathrm{CO}$ and low $\mathrm{O}_{3}$ occurring over northwest Mexico that subsequently was transported west then northward to California. Over the northern Plains, low $\mathrm{O}_{3}$ mixing ratios are also found in the UT that are associated with active deep convection in the region. High values of $\mathrm{O}_{3}$ over the Central Plains and Midwest are correlated with the stratosphere tracer. UT CO mixing ratios are 70-90 ppbv over most of the contiguous US (Fig. 5b) during this same period. High CO mixing ratios seen over the Gulf of Mexico and southeast US arise from air circulating around the anticyclone with an origin from a mesoscale 

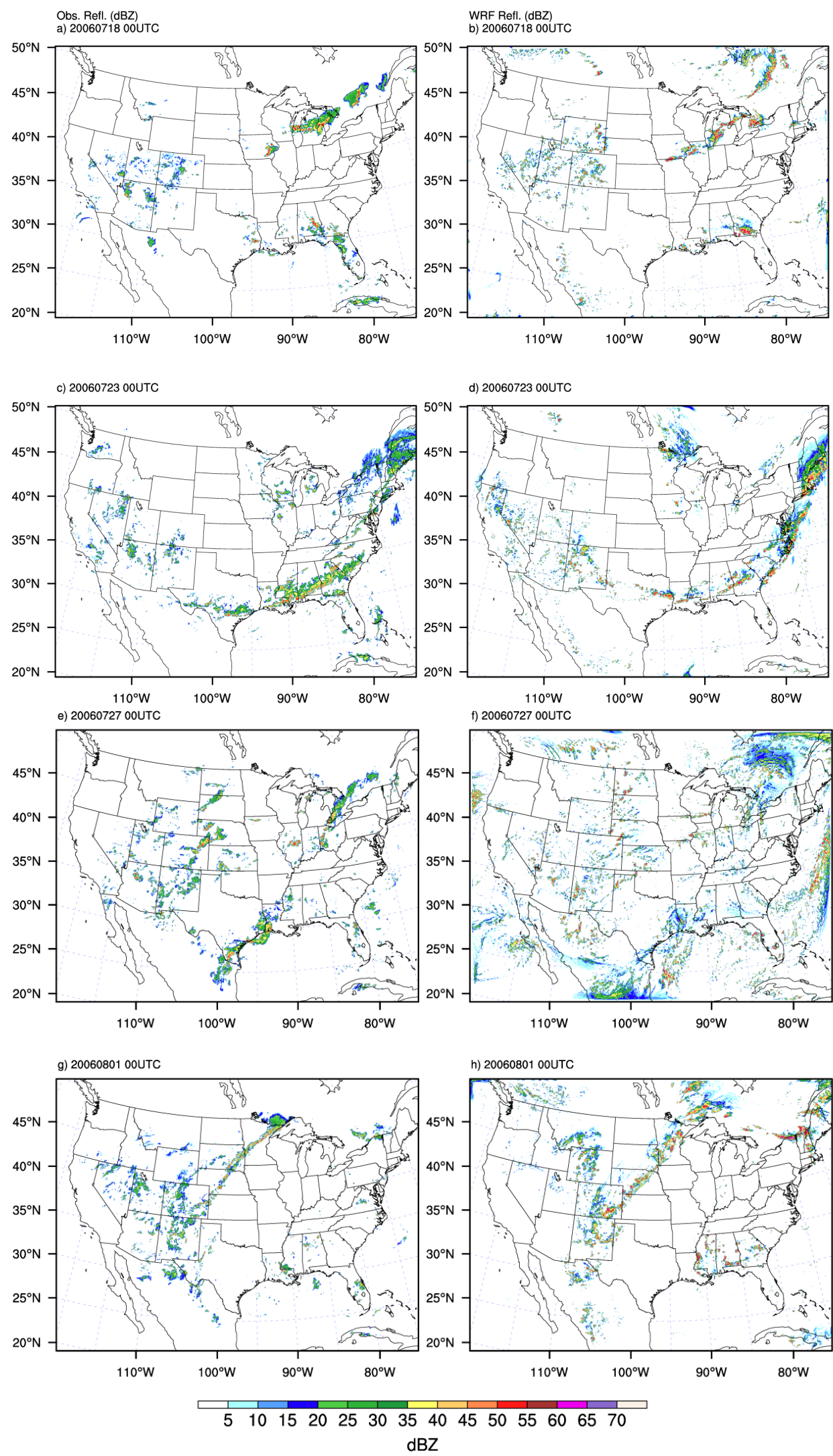

Fig. 3. National Weather Service NEXRAD observed (left panels) and WRF-Chem simulated (right panels) maximum radar reflectivity at 00:00 UTC for 18 July 2006 (a, b), 23 July 2006 (c, d), 27 July 2006 (e, f), and 1 August 2006 (g, h). Note that the observed radar reflectivity is only for the US while the model-derived reflectivity includes storms in Canada and Mexico. 
a) Rocky Mountain Region

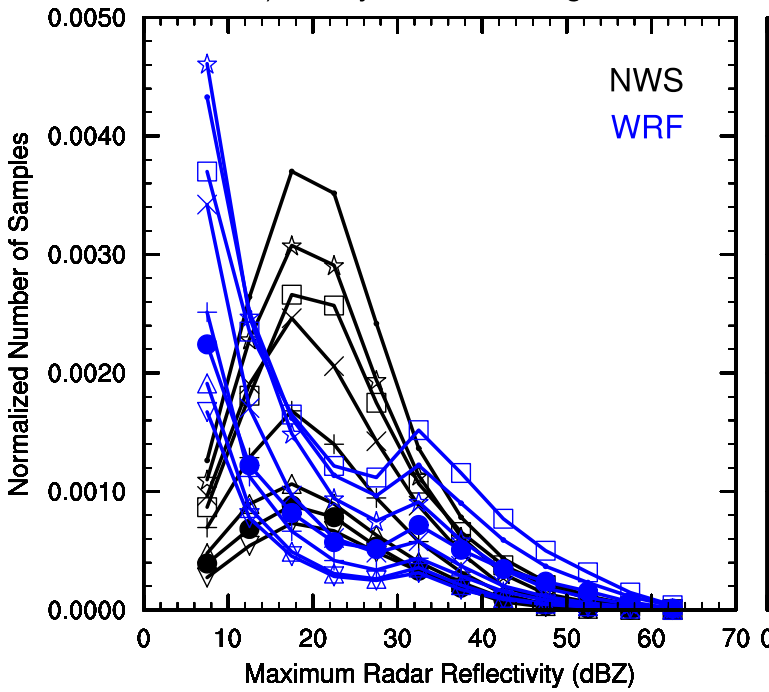

c) Central Plains Region

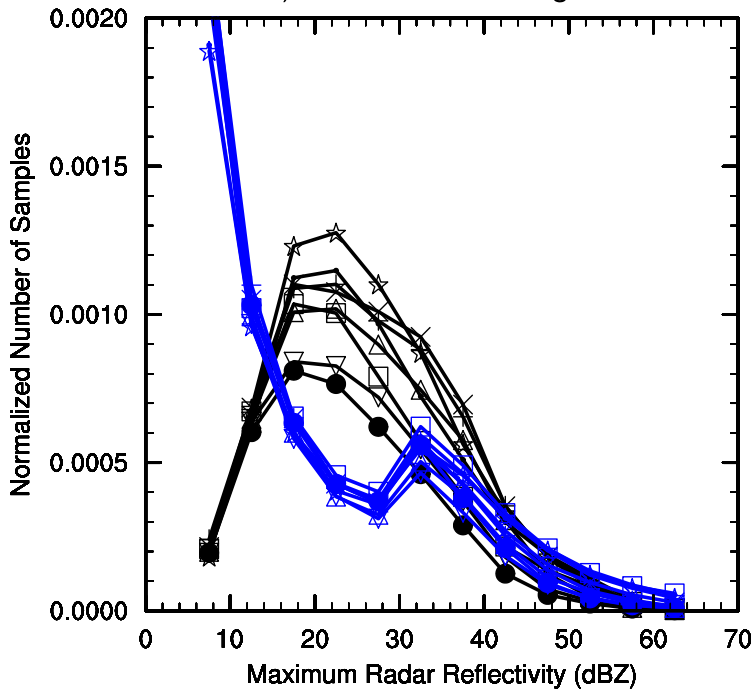

b) Gulf Coast Region

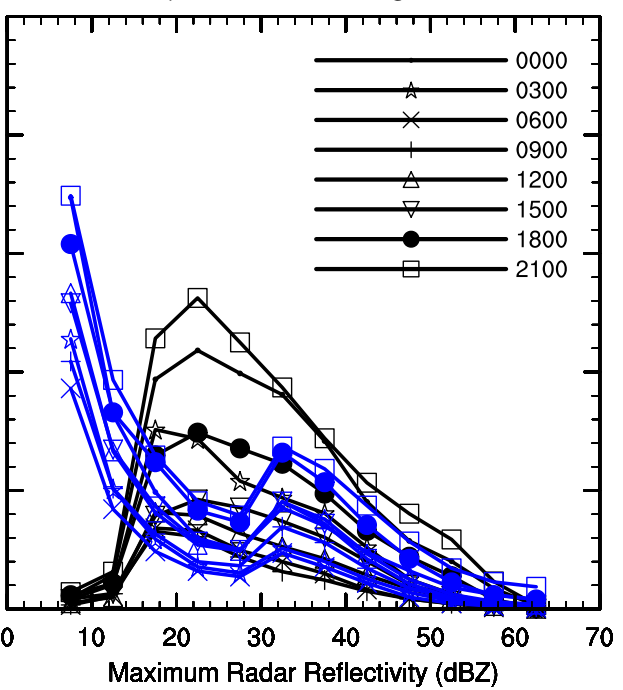

d) MidWest Region

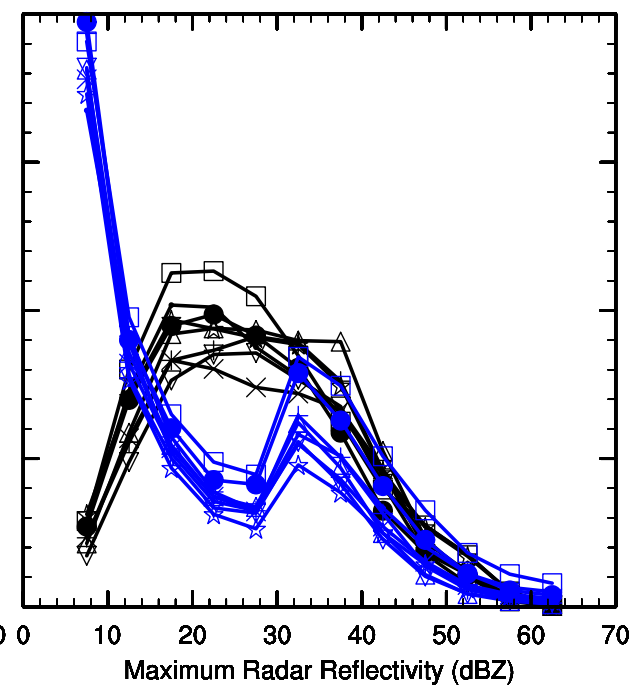

Fig. 4. Frequency distribution of radar reflectivity from observations (black lines) and model results (blue lines) at different hours of the day (see legend; time is UTC) for the 15 July to 6 August period. (a) Rocky Mountain region, (b) Gulf Coast region, (c) Central Plains region, and (d) Midwest region as shown in Fig. 1.

convective system over Kansas at the beginning of the simulation (10 July). This phenomenon is seen in both the WRFChem simulation and in the CAM-Chem simulation that initialized and provided boundary conditions for WRF-Chem.

During the 18-25 July period, when the anticyclone was situated over the western US, modeled $\mathrm{UT} \mathrm{O}_{3}$ mixing ratios over much of the contiguous US are 70-100 ppbv (Fig. 5c), where the lower mixing ratios are attributed to active convection transporting low $\mathrm{O}_{3}$ from the boundary layer to the UT over the northern Plains and to long range transport from the Pacific. High mixing ratios of modeled UT CO (Fig. 5d) are found along the Gulf Coast, northern Mexico, and the southwest US, which are regions influenced by convective transport and horizontal advection in the UT downstream of the deep convection.

During the 26-31 July period, when the anticyclone moved back over the central US, modeled UT $\mathrm{O}_{3}$ is high over the western US and northern half of the contiguous US (Fig. 5e), where air is being rapidly transported from west to east, indicating long-range transport that may be associated with stratospheric $\mathrm{O}_{3}$ upstream of the model domain. In the southern half of the US, the winds at $300 \mathrm{hPa}$ are much slower and circulate around the anticyclone allowing the accumulation and chemistry of $\mathrm{O}_{3}$ to occur. Modeled UT CO mixing ratios (Fig. 5f) are high over the southwest US near the center of the anticyclone where $\mathrm{CO}$ is accumulating. UT 
O3 concentration (ppbv)

a) 15-17 July 2006

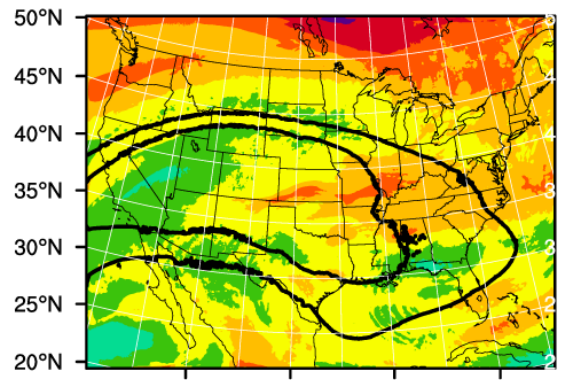

c) $18-25$ July 2006

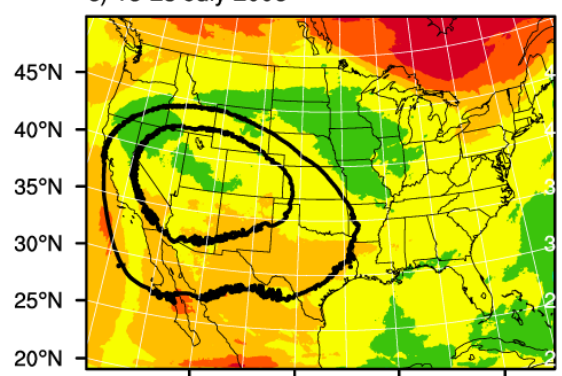

e) 26-31 July 2006

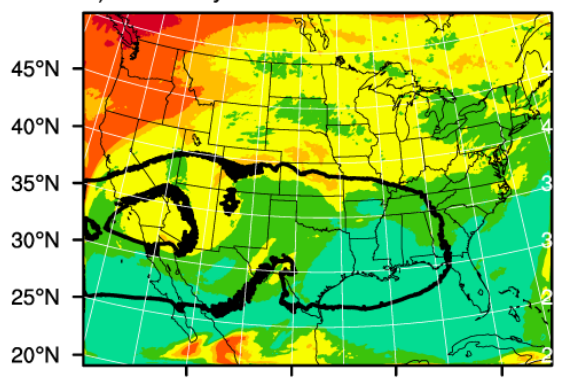

g) 1-6 August 2006

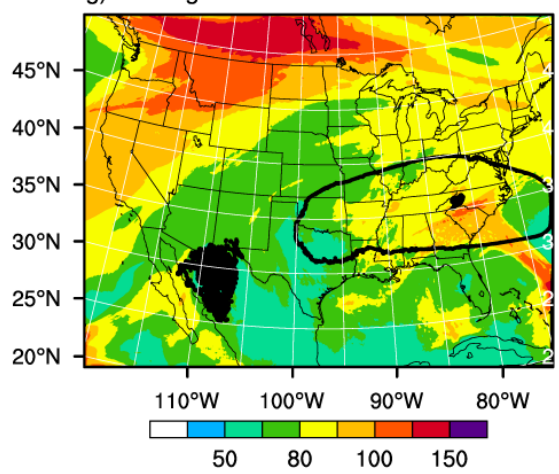

CO concentration (ppbv)

b) 15-17 July 2006

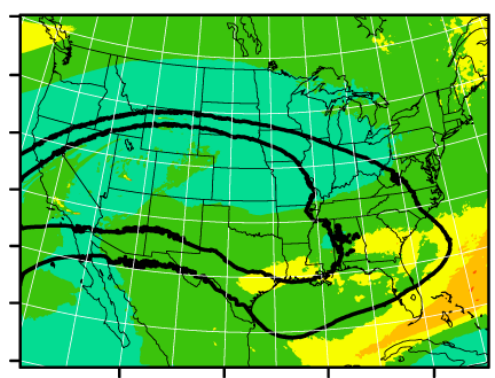

d) $18-25$ July 2006

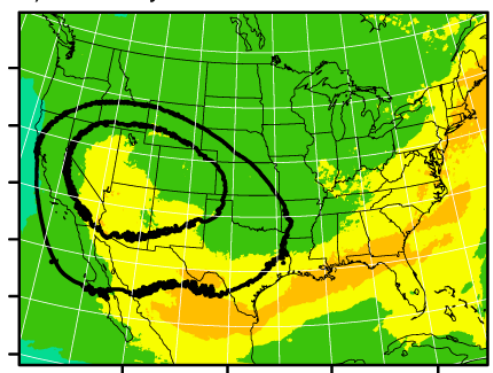

f) 26-31 July 2006

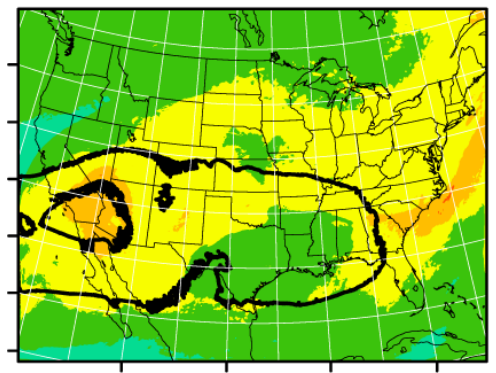

h) 1-6 August 2006

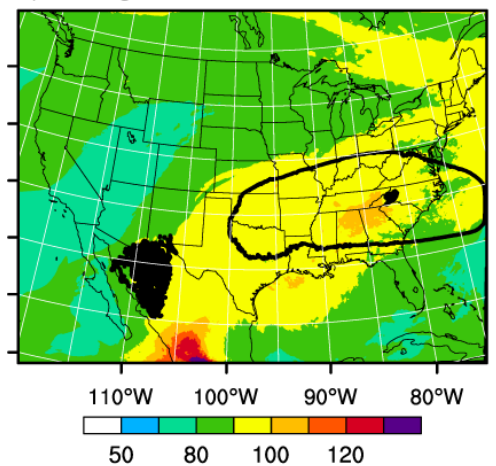

Fig. 5. Modeled $\mathrm{O}_{3}$ (left panels) and $\mathrm{CO}$ (right panels) at $300 \mathrm{hPa}$ averaged for the 4 time periods discussed in the text. Contour levels for $\mathrm{O}_{3}$ are 20,50, 70,80,90,100,120, and $150 \mathrm{ppbv}$ and for $\mathrm{CO}$ are 50, 70, 80, 90,100,110,120, and 150 ppbv. The 9725 and $9750 \mathrm{~m}$ heights indicate the location of the upper troposphere anticyclone. The black patch in northwest Mexico ( $\mathbf{g}$ and $\mathbf{h}$ ) is a region with geopotential height of $9725 \mathrm{~m}$.

$\mathrm{CO}$ mixing ratios are also high over the mid-Atlantic coast and are a result of convective transport either over the eastern US or over the northern US that was subsequently transported eastward.

During the 1-6 August period, the anticyclone moved to the Southeast and south-central US The simulated $\mathrm{O}_{3}$ at
$300 \mathrm{hPa}$ is found to be $>100 \mathrm{ppbv}$ in the center of this anticyclone (Fig. 5g) as a result of air entraining into the anticyclone region and accumulating in this area. The high $\mathrm{O}_{3}$ over Canada and the northwest US originates from the stratosphere. The modeled $\mathrm{CO}$ mixing ratios at $300 \mathrm{hPa}$ are high over the eastern US and low over the western US (Fig. 5h), 
a) WRF O3 2006-07-22 21:00:00

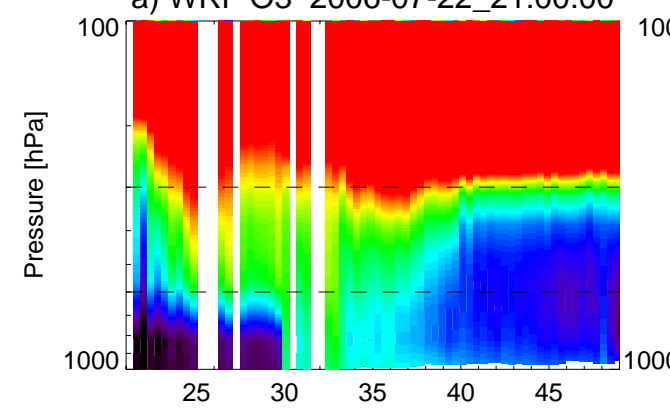

b) TES O3 2006-07-22 19:38:00

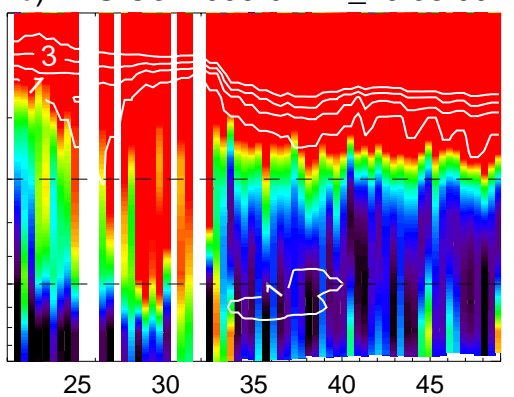

d) TES CO 2006-07-22_19:38:00
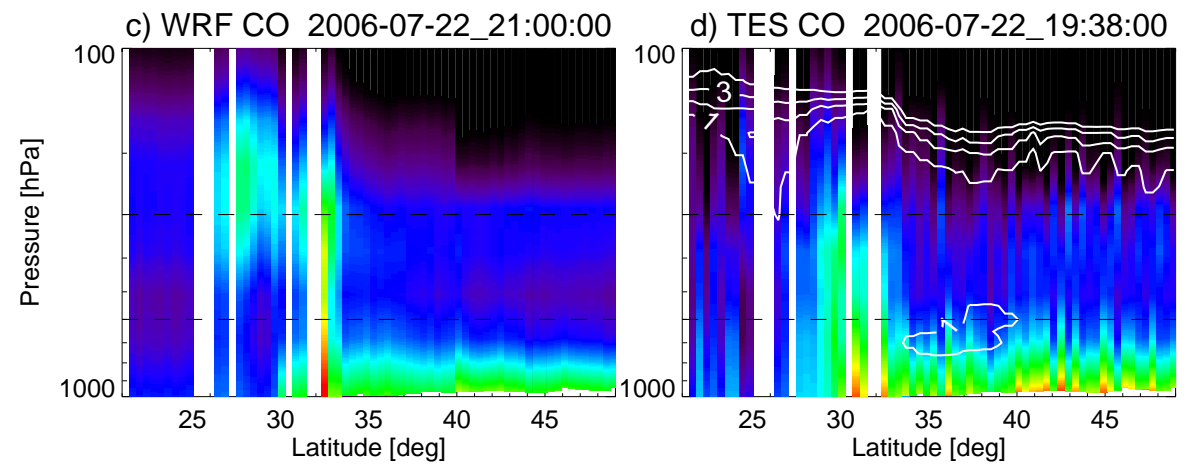

e)TES Track
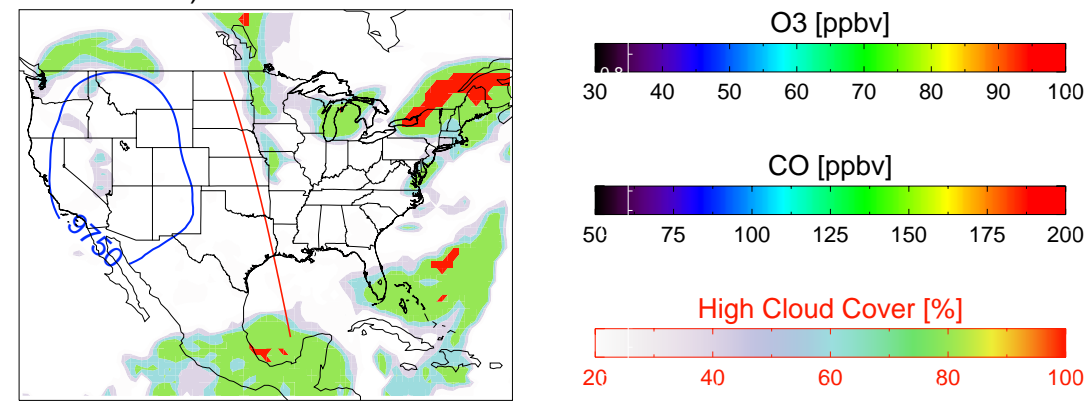

Fig. 6. $\mathrm{O}_{3}$ (a and b) and $\mathrm{CO}$ (c and $\left.\mathbf{d}\right)$ from the WRF-Chem simulation (a and $\mathbf{c}$ ) and the AURA/TES instrument ( b and d). The horizontal dashed lines mark the 300 and $600 \mathrm{hPa}$ levels. Results are plotted along the TES overpass track for 22 July 2006 over the central US as indicated in (e). The potential vorticity (b and d; 1, 2, 3, 4 PVU contours plotted), geopotential height, and high cloud cover (e) from the ERA-Interim 00:00 UTC analysis are also shown.

which is a result of clean air advecting in behind an eastward moving front.

\subsubsection{Comparison with observations}

To show an example of a comparison between WRF-Chem results and TES data, the orbit pass over the central US on 22 July 2006 at $\sim$ 19:40 UTC is used. This overpass is closest in time $(\sim 4 \mathrm{~h})$ with the west to east frontal convection occurring in Texas (Fig. 3c). The WRF-Chem simulation captures the general features of the $\mathrm{O}_{3}$ and $\mathrm{CO}$ distributions (Fig. 6). High ozone mixing ratios are seen above the $600 \mathrm{hPa}$ level for the $22-35^{\circ} \mathrm{N}$ latitude range for both the TES data and the WRF-Chem results. North of $35^{\circ} \mathrm{N}$ (behind the cold front) ozone mixing ratios are $<50 \mathrm{ppbv}$. While the WRF-Chem results do not have ozone mixing ratios as high as those shown by TES in the UT near $30^{\circ} \mathrm{N}$, the structure of the high ozone feature is quite similar to that seen in the TES data. The TES CO product shows $\mathrm{CO}$ mixing ratios of $>100 \mathrm{ppbv}$ reaching up to $300 \mathrm{hPa}$ near $30^{\circ} \mathrm{N}$ near the frontal convection (Fig. 6d). Likewise, the WRF-Chem results show evidence of convective lofting to the upper troposphere near the frontal convection but also further south over the Gulf of Mexico $\left(\sim 27^{\circ} \mathrm{N}\right)$ where air from the mid-Atlantic states was lofted a day or so earlier via convection.

To quantify the WRF-Chem upper troposphere $\mathrm{O}_{3}$ and CO mixing ratios with the TES data, frequency distributions are computed for the "step and stare" TES tracks passing over the model domain between 15 July and 6 August for 

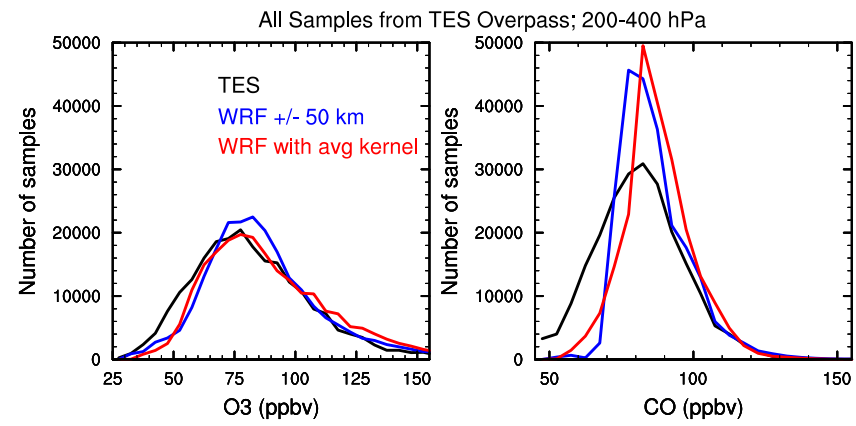

Fig. 7. Frequency distribution of $\mathrm{O}_{3}$ (left panel) and $\mathrm{CO}$ (right panel) for the 200-400 hPa altitudes from TES data (black line), WRF-chem results (blue line), and WRF-chem modified by the TES a priori and averaging kernel (red line) for 15 July to 6 August 2006 TES passes over the model domain.

the $200-400 \mathrm{hPa}$ altitude range. For points within $100 \mathrm{~km}$ of the TES overpass, WRF-Chem frequency distributions were computed based on raw output and also with output adjusted to take into account the influences of the TES averaging kernel. The frequency distribution for ozone (Fig. 7a) is broad with a peak of about 75 ppbv for both TES data and WRFChem results. The overlapping of the WRF-Chem results and TES data indicates that WRF-Chem is representing ozone in the UT well. The $\mathrm{CO}$ frequency distribution (Fig. 7b) has a narrower peak than the ozone distribution. Both TES and WRF-Chem CO peaks are at $80 \mathrm{ppbv}$. However, the frequency of high $\mathrm{CO}$ mixing ratios is $\sim 25 \%$ greater in the WRF-Chem simulation compared to TES, indicating that the model is lofting too much boundary layer air. The frequency difference between TES and WRF-Chem of low $\mathrm{O}_{3}$ is $<20 \%$ suggesting that in the model chemical production of $\mathrm{O}_{3}$ or stratosphere to troposphere transport of high $\mathrm{O}_{3}$ compensates for the excess convective lofting of $\mathrm{BL}$ air.

The ozonesonde data (Fig. 8) show high variability at Trinidad Head at $8-11 \mathrm{~km}$ altitude where much of the variance can be attributed to stratospheric air, as indicated by the low water vapor mixing ratios in the ozonesondes. The high variability was not replicated by WRF-Chem because often the stratosphere-troposphere exchange occurred upstream, outside the model domain. For both Trinidad Head and Huntsville ozonesondes, the agreement between observations and model results is quite good from the surface to $10 \mathrm{~km}$ or higher. The average ozone profile for Boulder shows that WRF-Chem overestimates ozone in the mid- to upper troposphere compared to observations, but predicted ozone is still within 1 standard deviation of observations from the surface to $13 \mathrm{~km}$ altitude. Above $12 \mathrm{~km}$, the WRFChem profiles for Huntsville and Boulder have much higher ozone mixing ratios than observed suggesting the tropopause is too low in WRF-Chem. This may be a result of the WRF configuration for WRF version 3.0.1 where the water vapor mixing ratio in the stratosphere is prescribed to be too high in the long-wave radiation algorithm (RRTM) causing a cold bias in the stratosphere (Cavallo et al., 2011). Between $15-20 \mathrm{~km}$, the WRF-Chem prediction of $\mathrm{O}_{3}$ remains high (within $20 \%$ ) compared to ozonesonde observations over the Huntsville site, but is similar in magnitude over the Boulder and Trinidad Head sites.

$\mathrm{O}_{3}$ and $\mathrm{CO}$ profiles for the MOZAIC locations (Fig. 9) show a reasonable agreement between observations and model results between the surface and $12 \mathrm{~km}$ altitude. Larger differences were found for $\mathrm{CO}$ below $2 \mathrm{~km}$ altitude with an overprediction of $\sim 50 \mathrm{ppbv}$ in modeled CO at Dallas. The low altitude measurements are in a region influenced by urban emissions. Therefore the comparison for the boundary layer should be interpreted as WRF-Chem over-predicting $\mathrm{CO}$ in a high emissions region and is not representative of the regional background concentrations that are more likely to be lofted by thunderstorms. For the $6-12 \mathrm{~km}$ altitude region, simulated $\mathrm{O}_{3}$ is $10-20,5-15$, and $0-30$ ppbv higher than observations for Atlanta, Dallas, and Portland, respectively. The modeled CO is generally lower than observations in this altitude range (by $<20 \mathrm{ppbv}$ for Atlanta and Dallas; $<25 \mathrm{ppbv}$ for Portland). All of the modeled profiles are within one standard deviation of the observations.

In summary, WRF-Chem predicts $\mathrm{CO}$ and $\mathrm{O}_{3}$ mixing ratios in the mid- to upper troposphere to within $10-20 \%$ of the satellite, ozonesonde, and MOZAIC measurements. On the other hand, the frequency distribution comparison between WRF-Chem and TES satellite data suggests that WRF-Chem is lofting $\mathrm{CO}$ too frequently from the boundary layer. Because the frequency of low ozone mixing ratios are not overpredicted with these same satellite data, it suggests that either chemical production of $\mathrm{O}_{3}$ in the model is overpredicted or there is too much stratosphere to troposphere transport in the model. The contribution of each of these ozone sources is discussed in the next section.

\section{Effect of convection on UT $\mathrm{CO}$ and $\mathrm{O}_{3}$ - geographic region perspective}

To examine the effect of convection from different geographic regions on UT $\mathrm{CO}$ and $\mathrm{O}_{3}$, time series of the areaaveraged mass of the species and tracers and the diagnostic ozone chemical tendency term are analyzed as well as the ozone chemical production based on the age of the BL tracer in the UT region.

\section{1 $\mathrm{CO}, \mathrm{O}_{3}$, and tracer masses}

Figure 10 shows the time evolution of the mass per $\mathrm{km}^{2}$ of $\mathrm{CO}$ and $\mathrm{O}_{3}$ in the 8-12 $\mathrm{km}$ altitude range during the 3week simulation analysis period as predicted by WRF-Chem. The decaying boundary layer and stratosphere tracers are also plotted to indicate the influx of air from those two regions. The decaying boundary layer and stratosphere tracers 


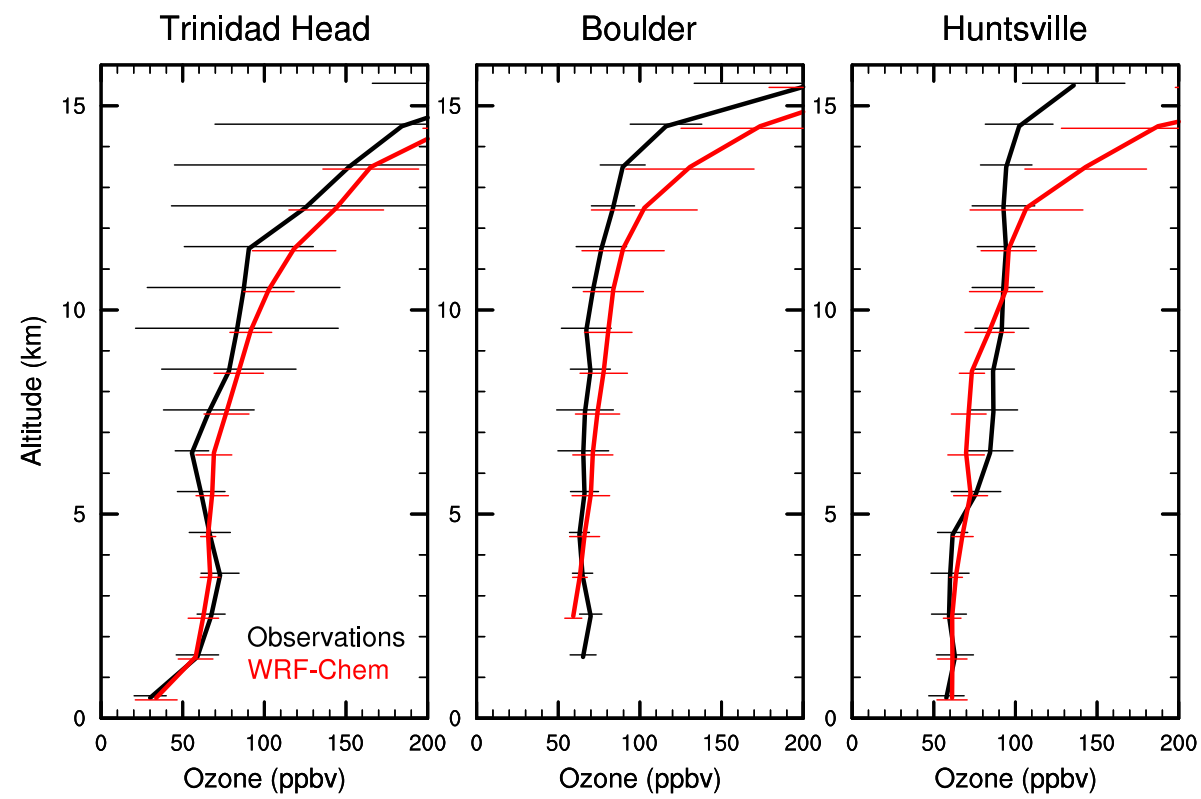

Fig. 8. Average $\mathrm{O}_{3}$ profiles from ozonesondes (black lines) and WRF-Chem (red lines) for (a) Trinidad Head, California, (b) Boulder, Colorado, and (c) Huntsville, Alabama. The profiles are averages over the 15 July to 6 August 2006 when ozonesondes were launched. The horizontal lines indicate the standard deviations for each of the profiles.

were unfortunately re-initialized to zero when meteorology re-starts occurred on 24 July and 2 August. The decaying boundary layer tracer time series shows the daily influx of boundary layer air through vertical transport, and its decay due to the 1-day lifetime. The daily variation is most pronounced in the Rocky Mountain area. However, the convective lofting of boundary layer air in the Rocky Mountain region is likely an overestimate based on the evaluation of radar reflectivity for the region (Sect. 3.1). The CO area-averaged mass does not show the same distinct daily variation that the decaying boundary layer tracer has, likely because $\mathrm{CO}$ has a chemical lifetime much longer than 1 day in the upper troposphere. During the 23 day period, the $\mathrm{CO}$ area-averaged mass in the upper troposphere increases slightly (10\% or less) in all regions except the Rocky Mountains, which experiences a $20 \%$ increase for the first 17 days and then a strong decrease after the passage of the cold front on 1 August. These same trends for each region can be seen in the plots of Fig. 5.

The decaying stratosphere tracer has episodic increases associated with either stratosphere-troposphere dynamics north of the jet stream (31 July to 1 August in the West Coast region) or with cold front passages (22-24 July in the Midwest). There is a correlated increase in $\mathrm{O}_{3}$ area-averaged mass for these same time periods indicating that the high ozone mixing ratios are from the stratosphere. During the 18-25 July period when the anticyclone was situated over the western US, the $\mathrm{O}_{3}$ area-averaged mass in the upper troposphere increases from $2.25 \mathrm{~kg} \mathrm{~km}^{-2}$ to $2.75 \mathrm{~kg} \mathrm{~km}^{-2}$, a $22 \%$ increase, which is a result of high $\mathrm{O}_{3}$ being transported into the West Coast region from northwest Mexico and low $\mathrm{O}_{3}$ being transported out of the West Coast region. The other regions do not show an increase in $\mathrm{O}_{3}$ area-averaged mass coincident with the anticyclone location in that region (e.g. the Central Plains $\mathrm{O}_{3}$ area-averaged mass decreases when the anticyclone is over the central US during 15-17 July and 2631 July). However, the $\mathrm{O}_{3}$ area-averaged mass over the Gulf Coast substantially increases $\left(2.0 \mathrm{~kg} \mathrm{~km}^{-2}\right.$ to $2.7 \mathrm{~kg} \mathrm{~km}^{-2}$ or $35 \%$ increase) from 30 July to 1 August, which is a result of high ozone originally from the stratosphere moving from the Midwest (note the peak in $\mathrm{O}_{3}$ and stratosphere tracer in the Midwest on the 29 July) into the Gulf Coast region and subsequently being accumulated by the anticyclone that is in place in early August.

The UT masses of the BL and stratosphere tracers can be used to get an idea of the ability for a coarser horizontal grid spacing simulation to parameterize convection compared with the $4 \mathrm{~km}$, convective-system permitting simulation presented here. Results from a simulation at $36 \mathrm{~km}$ grid spacing for a 6-day period (17-22 July ) are compared to the results shown in Fig. 10. The comparison reveals that the UT masses per area of $\mathrm{CO}, \mathrm{O}_{3}, \mathrm{BL}$ tracer, and stratosphere tracer for the 5 geographic regions have similar magnitudes of mass for both simulations (the $36 \mathrm{~km}$ simulation used the Grell and Devenyi (2002) cumulus parameterization), but differ somewhat in the daily variation likely because the $4 \mathrm{~km}$ simulation is able to represent some venting by scattered convection. For example, the daily injection of BL tracer into the UT over the Rocky Mountains does not always occur for the convective parameterization run. There are larger differences with the stratosphere tracer mass where the $4 \mathrm{~km}$ simulation predicts 
a) ATLANTA

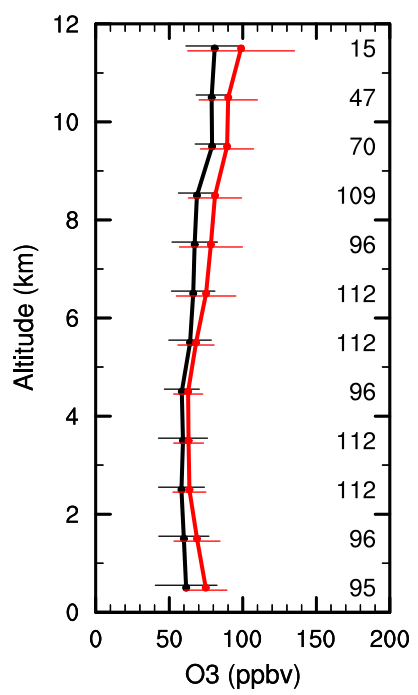

d) ATLANTA

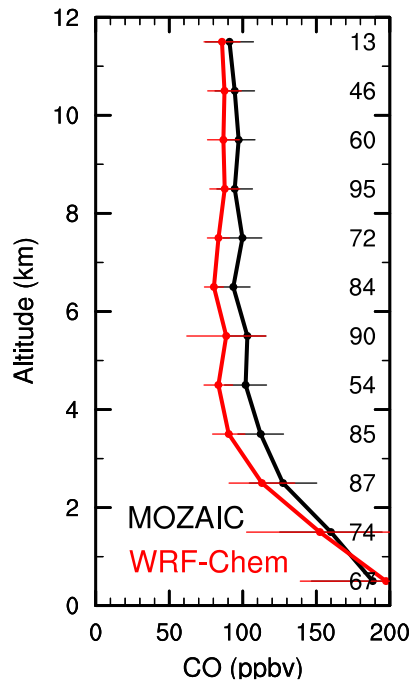

b) DALLAS

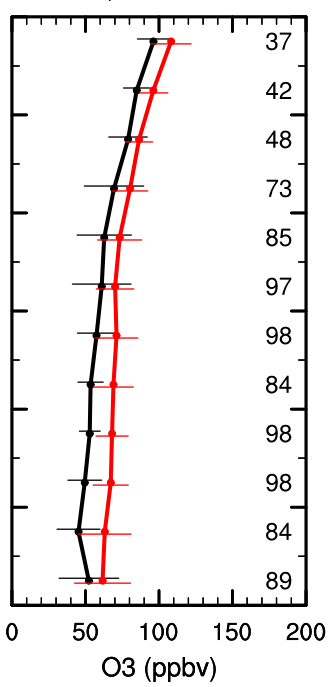

e) DALLAS

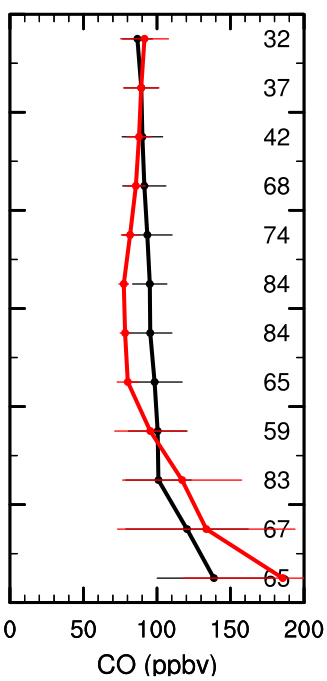

c) PORTLAND

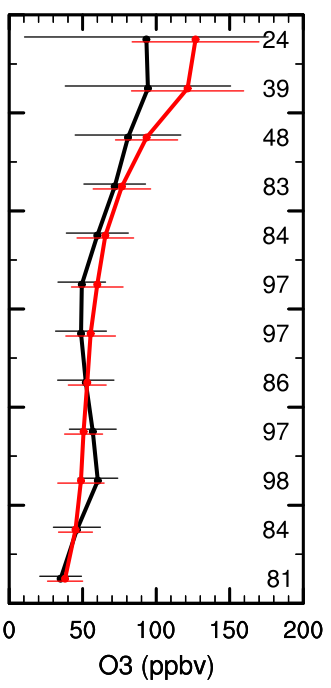

f) PORTLAND

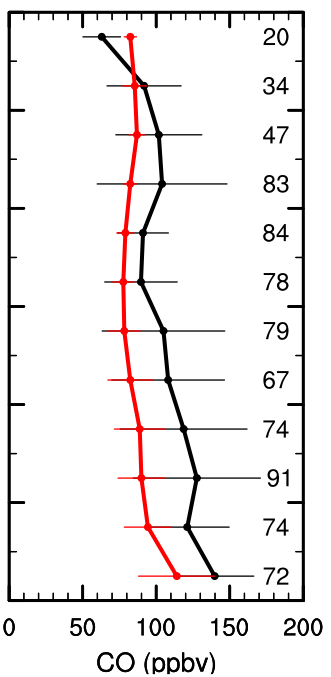

Fig. 9. Average vertical profiles of $\mathrm{O}_{3}(\mathbf{a}-\mathbf{c})$ and $\mathrm{CO}(\mathbf{d}-\mathbf{f})$ mixing ratios from the MOZAIC data (black lines) and the WRF-Chem simulation (red lines) binned into altitude levels. The profiles are averages over the 15 July to 3 August 2006 when MOZAIC profiles were available. The horizontal lines indicate the standard deviation for each of the datasets and the numbers on the right side of the plots are the number of samples for each altitude bin.

more stratospheric air entering the UT than the $36 \mathrm{~km}$ simulation, especially for the Midwest region behind the cold front on the 22 July. Thus, our convective-system permitting simulation produces consistent daily lofting of BL air to the UT and enhances the stratosphere to troposphere transport.

\subsection{Ozone production}

Figure 10 includes the time evolution of the ozone chemical tendency per $\mathrm{km}^{2}$ in the $8-12 \mathrm{~km}$ altitude region as predicted by WRF-Chem. The ozone chemical tendency is the difference between $\mathrm{O}_{3}$ before and after the chemical solver routine in WRF-Chem and we plot the values averaged over $3 \mathrm{~h}$ pe- riods. While most of the convective transport occurs in the Rocky Mountain region (Fig. 10), most of the ozone chemical tendency occurs over the Gulf Coast and Midwest regions where VOCs other than $\mathrm{CO}$ and $\mathrm{CH}_{4}$ are more abundant near the surface. The West Coast shows the lowest net $\mathrm{O}_{3}$ production per area of all 5 regions.

There are apparent correlations between the tracers and the $\mathrm{O}_{3}$ production. Generally, when stratospheric air is in the region the $\mathrm{O}_{3}$ production is less than when $\mathrm{O}_{3}$ is not enhanced from stratospheric influences because $\mathrm{O}_{3}$ precursors, including $\mathrm{CO}$ and VOCs, are also smaller in magnitude when stratospheric air is in the region. These instances are most prominently seen (Fig. 10) in the Midwest from 22 to 

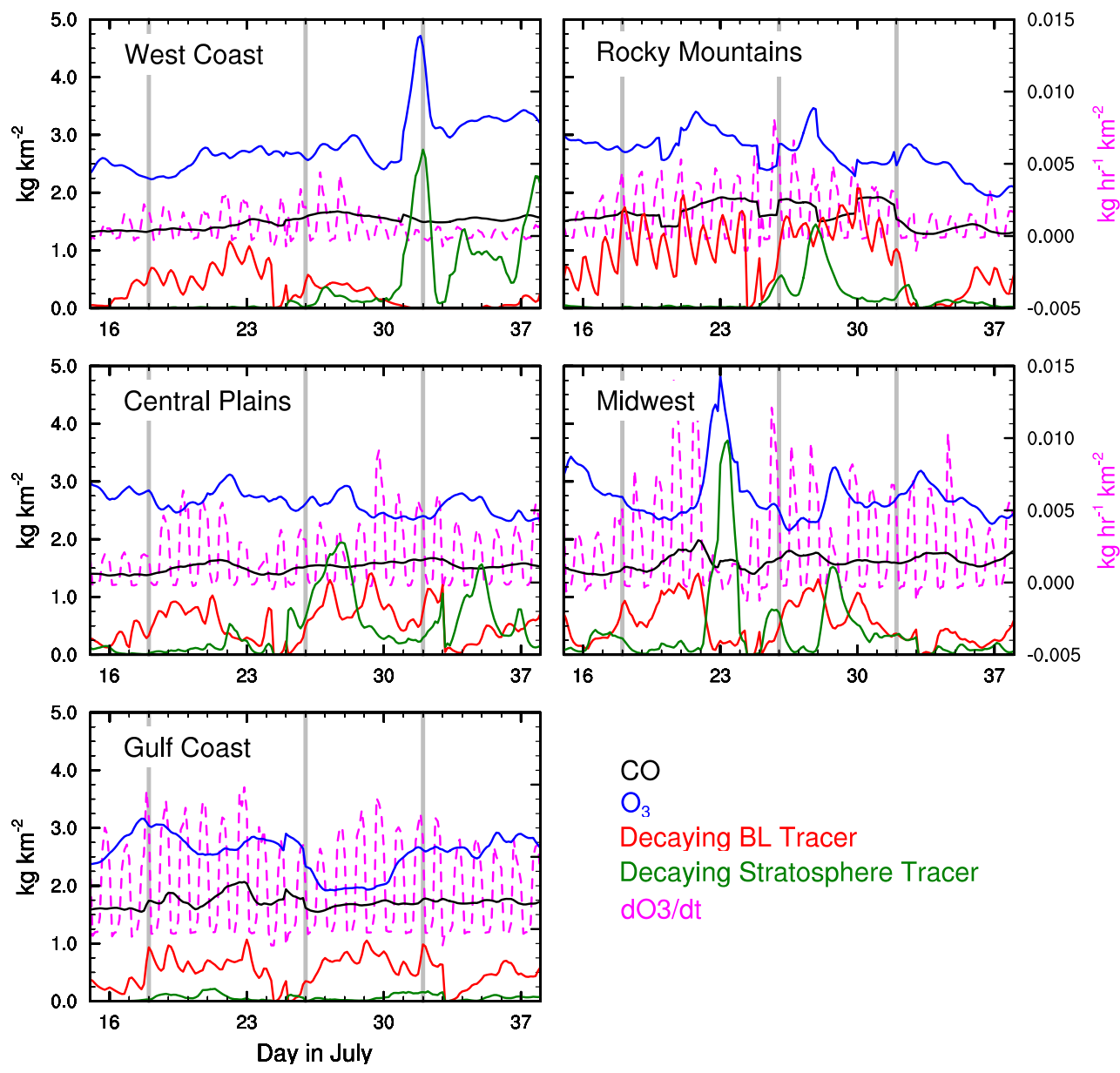

$\mathrm{CO}$

$\mathrm{O}_{3}$

Decaying BL Tracer

Decaying Stratosphere Tracer

$\mathrm{dO} 3 / \mathrm{dt}$

Fig. 10. Mass per unit area of $\mathrm{CO}$ (black line), $\mathrm{O}_{3}$ (blue line), decaying boundary layer tracer (red line), decaying stratosphere tracer (green line), and chemical ozone tendency (dashed magenta line; right axis) in the upper troposphere (8-12 km altitude range) over the (a) West Coast, (b) Rocky Mountains, (c) Central Plains, (d) Midwest, and (e) Gulf Coast regions of the model domain as shown in Fig 1. The decaying boundary layer scalar and decaying stratosphere tracer masses per area are the respective masses of air in units of $2 \times 10^{6} \mathrm{~kg} \mathrm{~km}^{-2}$ and $1 \times 10^{6} \mathrm{~kg} \mathrm{~km}^{-2}$, respectively. The vertical gray lines delineate the 4 meteorological periods as described in the text.

25 July and on 28 July, in the West Coast from 31 July to 2 August, and in the Rocky Mountains from 27 to 29 July. There are also several times when the decaying boundary layer tracer and the $\mathrm{O}_{3}$ production increase together indicating more $\mathrm{O}_{3}$ production occurring in fresh boundary layer air that has been transported to the upper troposphere than in the background upper troposphere air. These instances are easily seen (Fig. 10) in the Gulf Coast region for 17-23 July and 27 July-1 August, in the Central Plains for 16-22 July and 29 July to 2 August, and in the Midwest from 20-22 July and 26-28 July. The West Coast has relatively higher $\mathrm{O}_{3}$ production in the upper troposphere soon after the anticyclone has moved from the West Coast to the Central Plains (2627 July). The increase of $\mathrm{O}_{3}$ over the West Coast from 1820 July is not correlated with either in situ ozone production or stratospheric air, but instead is a result of high $\mathrm{O}_{3}$ air being advected into the region from northwestern Mexico.

\section{$5.3 \mathrm{O}_{3}$ production based on age of air in each region}

To further understand when and where ozone is being produced in the upper troposphere, the model results for the 8$12 \mathrm{~km}$ altitude region are sampled based on the age of the air since it has left the boundary layer and on the geographical region. The age of air, as described in Sect. 2.3, is determined from the logarithm of the ratio of the passive to the decaying boundary layer tracer. Because mixing of new boundary layer air with old air can result in an age representing neither young nor old air, the analysis is performed using broad age categories: 0-12 h, 12-24h, 24-48 h, 48-72 h, and 72-120 h since the air exited the boundary layer. As described above, the ozone chemical tendency and reaction rates are calculated at each grid point in the $8-12 \mathrm{~km}$ altitude range throughout the model domain. Within each region, the age of air is also calculated at each grid point between 8 and $12 \mathrm{~km}$ altitude. The rate is identified per region and age of air, summed for 
a) Rocky Mtns, July 15-17

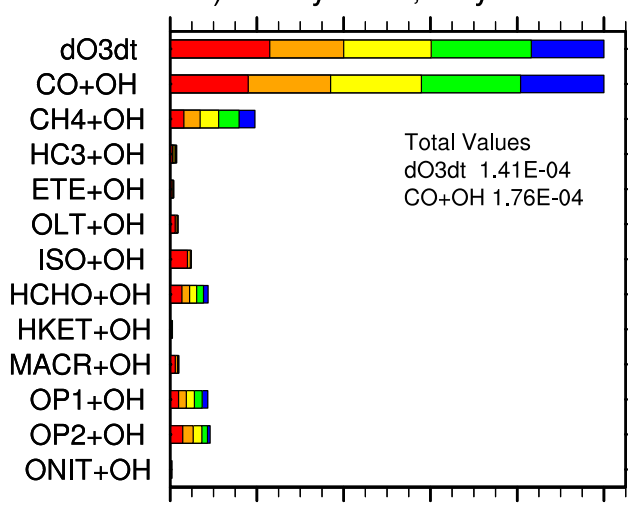

c) Rocky Mtns, July 26-31

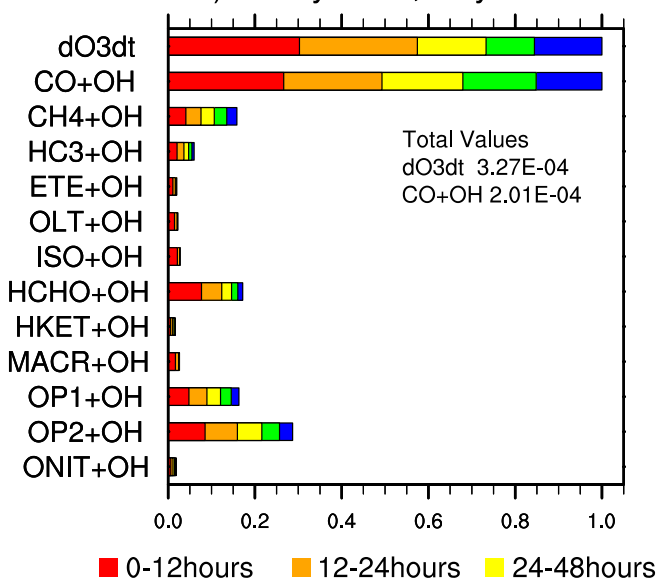

b) Rocky Mtns, July 18-25

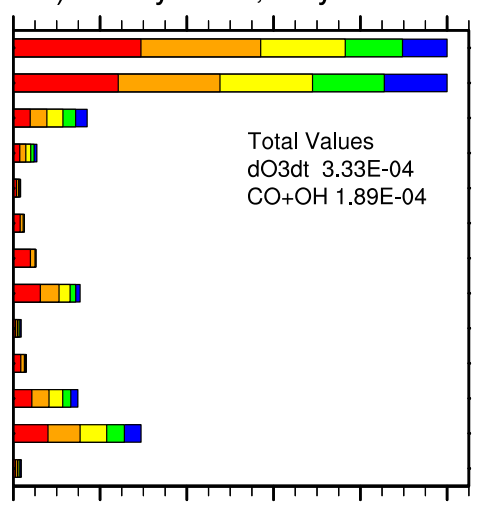

d) Rocky Mtns, August 1-7

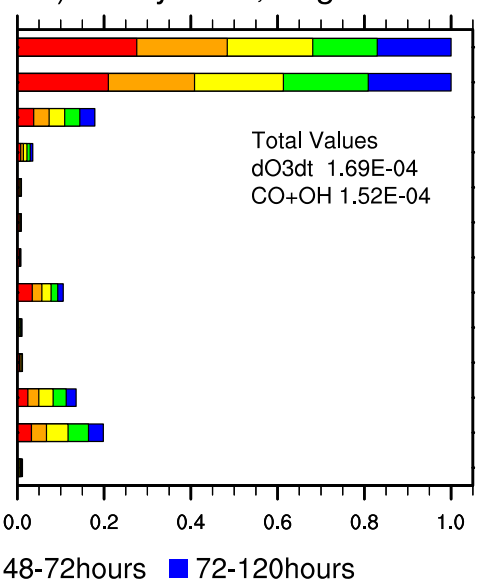

Fig. 11. The contribution of various VOC oxidation reactions to peroxy radical formation is shown as a function of the age of air for the Rocky Mountain region. Each contribution is an average for the upper troposphere (8-12 km altitude range) over the four time periods described in the meteorology section of the paper. The $\mathrm{dO}_{3} \mathrm{dt}$ and $\mathrm{CO}+\mathrm{OH}$ rates are normalized by their total value (listed in the panel) in the region and time period, while the other reaction rates are normalized by the $\mathrm{CO}+\mathrm{OH}$ total value in the region and time period. The Rocky Mountain region is shown in Fig. 1.

each category, and then divided by the number of grid points in each category to give a rate per volume result. The results are further averaged over the four meteorological time periods, 15-17 July, 18-25 July, 26-31 July, and 1-7 August, so as to examine the net ozone production in the context of the meteorological scenario.

In a similar fashion, the rates of several oxidation reactions that form peroxy radicals (and presumably further react with $\mathrm{NO}$ to form $\mathrm{NO}_{2}$ ) are determined. In thunderstorm outflow regions, where NO generated from lightning exists, there should be sufficient NO to react with the peroxy radicals such that $\mathrm{NO}_{2}$ and subsequently $\mathrm{O}_{3}$ are produced. While the role of lightning- $\mathrm{NO}_{\mathrm{x}}$ in these simulations will be analyzed in a future paper, evaluation of the lightning flash rate with NLDN data shows that the flash rate is underpredicted (Wong et al., 2012). Here, we focus on the contribution of specific $\mathrm{VOC}+\mathrm{OH}$ oxidation reactions to form peroxy radicals to understand where and when the oxidation occurs in the convective outflow regions. Several reactions in the
RACM mechanism produce peroxy radicals. These reactions include oxidation by $\mathrm{OH}$ of $\mathrm{CO}, \mathrm{CH}_{4}$, propane (HC3), ethene (ETE), terminal olefins (OLT), isoprene (ISO), formaldehyde (HCHO), hydroxy-ketone (HKET), methyl hydroperoxide (OP1), other organic peroxides (OP2), and organic nitrates (ONIT). Note that these last two are compounds representing a group of compounds and not any specific member of the group. The reaction rates were calculated using the model output of the temperature and pressure (to calculate the rate coefficient) and the mixing ratios.

The Rocky Mountain (Fig. 11) and Gulf Coast (Fig. 12) regions are used to illustrate the results, but the results are discussed for all regions. The ozone chemical tendency and the $\mathrm{CO}+\mathrm{OH}$ reaction rate are normalized by their respective total value, as listed in the figure, for each region and meteorological time period. The other reaction rates of hydrocarbons with $\mathrm{OH}$ are normalized by the $\mathrm{CO}+\mathrm{OH}$ total rate to show the relative importance of each reaction. 
a) Gulf Coast, July 15-17

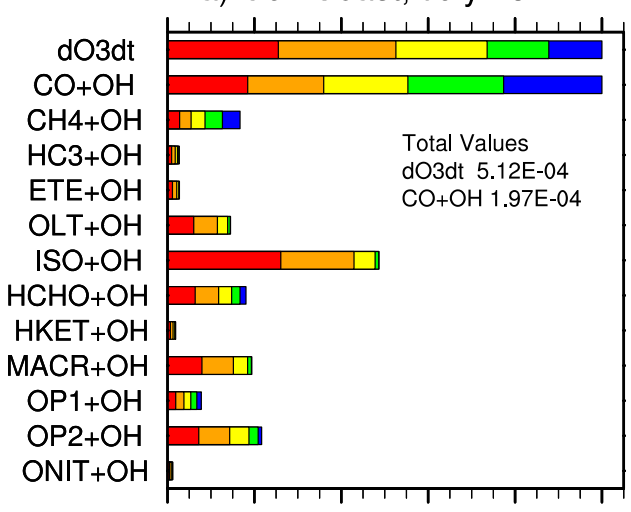

c) Gulf Coast, July 26-31

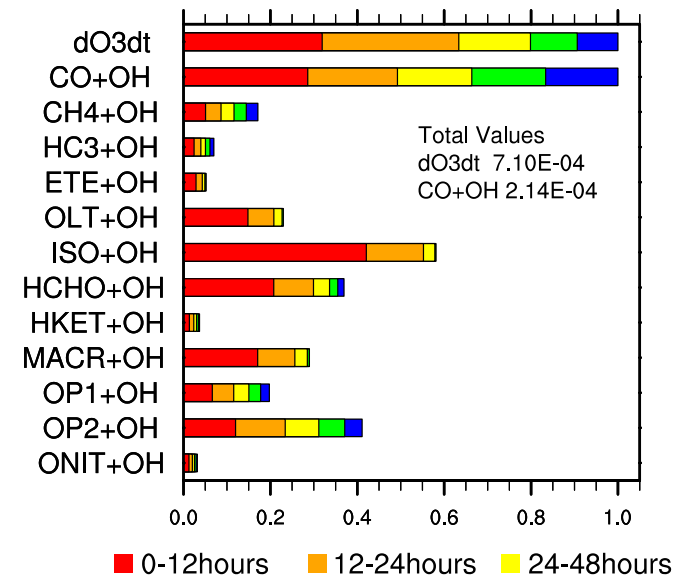

b) Gulf Coast, July $18-25$

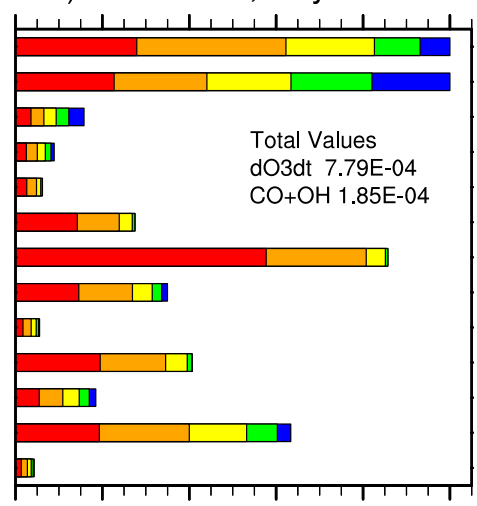

d) Gulf Coast, August 1-7

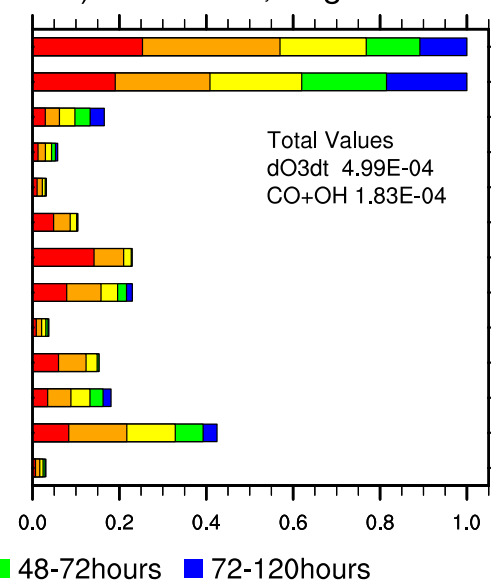

Fig. 12. The same as Fig. 11 but for the Gulf Coast region, which is shown in Fig. 1.

The analysis shows that more than half of the ozone production (e.g., Figs. 11-12) takes place in the first $24 \mathrm{~h}$ after convective lofting for all the geographic regions, Many of these storms occur in the late afternoon to evening (Fig. 4), thus the next day's photochemistry is responsible for the chemical production of ozone. Recall, that the predicted convection is $\sim 3 \mathrm{~h}$ earlier than observed convection in these two regions (Fig. 4). Thus, in reality, it is even more so that the chemical ozone production is occurring during the next day. Interestingly, the convective outflow over the Central Plains experiences most of its ozone production in air 12$24 \mathrm{~h}$ old; convective outflows from afternoon thunderstorms over the Rocky Mountain region move eastward into the Central Plains where oxidation occurs the following morning, and additionally some of these same storms propagate eastward into the Central Plains at night, but their outflows do not undergo oxidation until daylight.

The oxidation rates for all the regions and meteorological time periods show that $\mathrm{CO}+\mathrm{OH}$ is the dominant pathway for producing peroxy radicals, but oxidation of organic peroxides (OP2 in Figs. 11-12), methane, $\mathrm{HCHO}$, and $\mathrm{CH}_{3} \mathrm{OOH}$ (OP1 in Figs. 11-12) are important contributors to peroxy radical production. The organic peroxides are important for producing peroxy radicals, but their predicted production may not be realistic because of assumptions in the parameterized chemistry or underpredicted lightning $\mathrm{NO}_{\mathrm{x}}$. In addition, observational studies (e.g. Snow et al., 2007) have not shown appreciable concentrations of these compounds in the upper troposphere. Thus, a careful examination of the role of organic peroxides in the upper troposphere chemistry should be pursued.

Oxidation by $\mathrm{OH}$ of VOCs other than $\mathrm{CO}, \mathrm{CH}_{4}, \mathrm{HCHO}$, and organic peroxides can be important in the Central Plains, Midwest, and Gulf Coast regions. The Central Plains and Midwest regions include oxidation of species of anthropogenic origin, such as propane. Over the Gulf Coast region, oxidation of isoprene and its products (e.g. MACR) in the convective outflow is very important (Fig. 12) for producing peroxy radicals, while isoprene oxidation has little contribution to peroxy radical formation over the Rocky Mountains.

In summary, this analysis shows that (a) more than half of the ozone production takes place in the first $24 \mathrm{~h}$ after convective lofting for all geographic regions, (b) organic peroxides are important for producing peroxy radicals, but their predicted production may not be realistic because of assumptions in the parameterized chemistry or possibly 


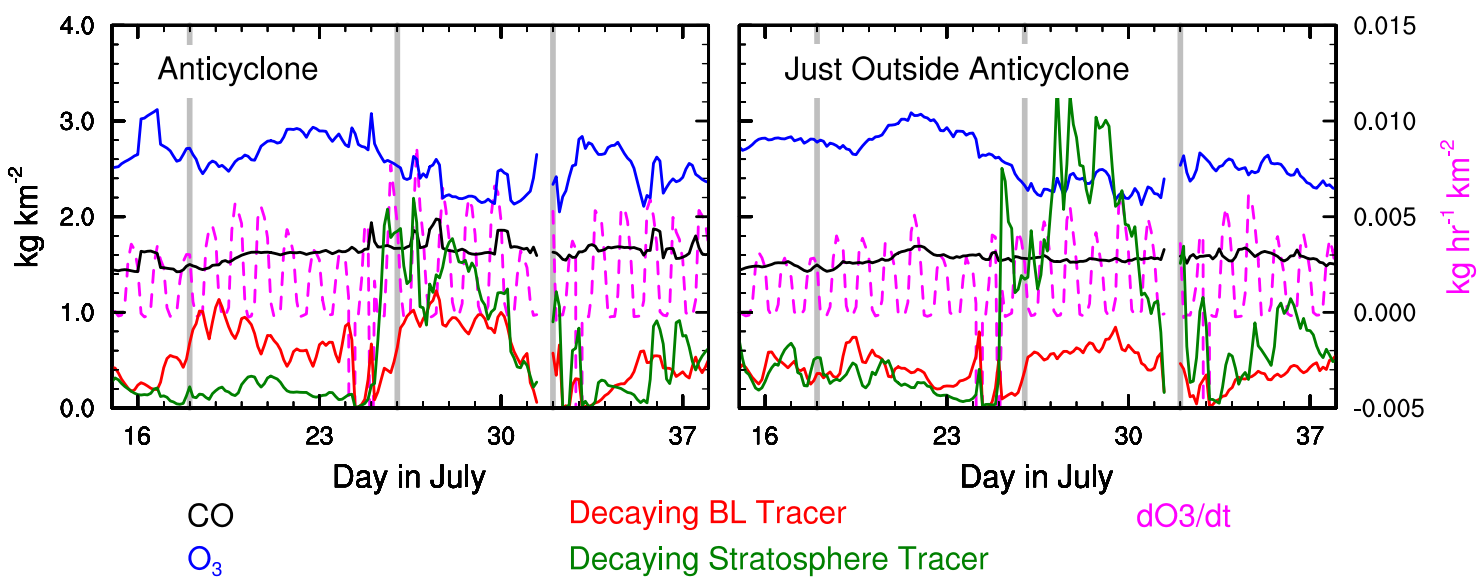

Fig. 13. Mass per unit area of $\mathrm{CO}$ (black line), $\mathrm{O}_{3}$ (blue line), decaying boundary layer tracer (red line), and decaying stratosphere tracer (green line), and chemical ozone tendency (dashed magenta line; right axis) in the upper troposphere (8-12 km altitude range) within the Anticyclone and Just Outside the Anticyclone. The horizontal area of the Anticyclone is defined as the region by $\mathrm{z}>9730 \mathrm{~m}$ at $300 \mathrm{hPa}$. The horizontal area of the Just Outside Anticyclone region is defined as the region by $9730 \mathrm{~m}>z>9680 \mathrm{~m}$ at $300 \mathrm{hPa}$ and only includes grid points within $600 \mathrm{~km}$ of the Anticyclone. The boundary layer scalar and stratosphere tracer masses per area are the respective masses of air in units of $2 \times 10^{6} \mathrm{~kg} \mathrm{~km}^{-2}$ and $1 \times 10^{6} \mathrm{~kg} \mathrm{~km}^{-2}$, respectively. On the $31 \mathrm{July}$, geopotential heights were $<9730 \mathrm{~m}$, so the Anticyclone could not be located.

underpredicted lightning $\mathrm{NO}_{\mathrm{x}}$, and (c) anthropogenic VOCs (e.g. propane) are important peroxy radical precursors in the Central Plains and Midwest, while isoprene and its oxidation products are important in the Gulf Coast region for peroxy radical production.

\section{Effects of convection on UT $\mathrm{CO}$ and $\mathrm{O}_{3}$ - anticyclone perspective}

To examine the processes producing and maintaining high ozone mixing ratios within the anticyclone (as observed in previous studies e.g. Cooper et al., 2007), the model output can be sampled for air within the upper troposphere anticyclone and just outside the anticyclone. For both regions, a volume of air is sampled from 8 to $12 \mathrm{~km}$ altitude. The mass of $\mathrm{CO}, \mathrm{O}_{3}$, decaying boundary layer tracer, and decaying stratosphere tracer are normalized by the area of the anticyclone or the region just outside the anticyclone as defined at the $300 \mathrm{hPa}$ pressure level. The anticyclone exists on all days of the simulation except on the 31 July when the anticyclone weakened and geopotential heights were less than $9730 \mathrm{~m}$.

Because the model simulation contained a passive tracer of stratospheric air instead of a stratospheric $\mathrm{O}_{3}$ tracer (e.g. Roelofs and Lelieveld, 1997; Wang et al., 1998), correlations between $\mathrm{O}_{3}$ and the stratosphere tracer are used to determine contributions from the stratosphere. As a result, it is not possible to quantify the contribution of various $\mathrm{O}_{3}$ sources here.

\section{1 $\mathrm{CO}, \mathrm{O}_{3}$, and tracer masses}

Figure 13 shows the mass per square kilometer of $\mathrm{CO}, \mathrm{O}_{3}$, decaying boundary layer tracer, and decaying stratosphere tracer for the anticyclone and just outside the anticyclone. The $\mathrm{CO}$ and $\mathrm{O}_{3}$ area-averaged mass is similar for the two regions (1.4 to $1.8 \mathrm{~kg} \mathrm{~km}^{-2}$ for $\mathrm{CO}$ and 2.0 to $3.2 \mathrm{~kg} \mathrm{~km}^{-2}$ for $\mathrm{O}_{3}$ ), although during the last week of the simulation there is somewhat more $\mathrm{CO}$ and $\mathrm{O}_{3}$ in the anticyclone, which is located over the southeastern and south central US, than just outside the UT anticyclone. The decaying boundary layer and stratosphere tracers show much more variability than $\mathrm{CO}$ and $\mathrm{O}_{3}$. Especially in the anticyclone, there is a diurnal variability for the BL tracer indicating a daily lofting of the boundary layer air to the upper troposphere within the anticyclone. However, there are specific periods during which stratospheric air resides in the anticyclone (e.g. 25-30 July) indicating that while BL air is being lofted stratospheric air is also being entrained into the upper troposphere. During the 18-31 July time periods (West Coast anticyclone that then transitions to the central US), the decaying boundary layer tracer is $30-35 \%$ greater within the anticyclone compared to just outside the anticyclone. In contrast, the decaying stratosphere tracer is always smaller within the anticyclone compared to just outside the anticyclone.

These results contrast to previous studies that found UT $\mathrm{O}_{3}$ mixing ratios to be up to $40 \mathrm{ppbv}$ greater than upwind locations (Cooper et al., 2007). There are two important differences between our results and the Cooper et al. study. First, the timing of the study periods is different. Our study focuses on 15 July to 7 August when the anticyclone moved from the central, to western, to southeastern US, while Cooper et al. (2007) focused on the monthly average of August 2006 when the anticyclone was more stationary over the southeastern and south central US. Because the more stationary anticyclone remained over a region rich in VOCs, ozone precursors 


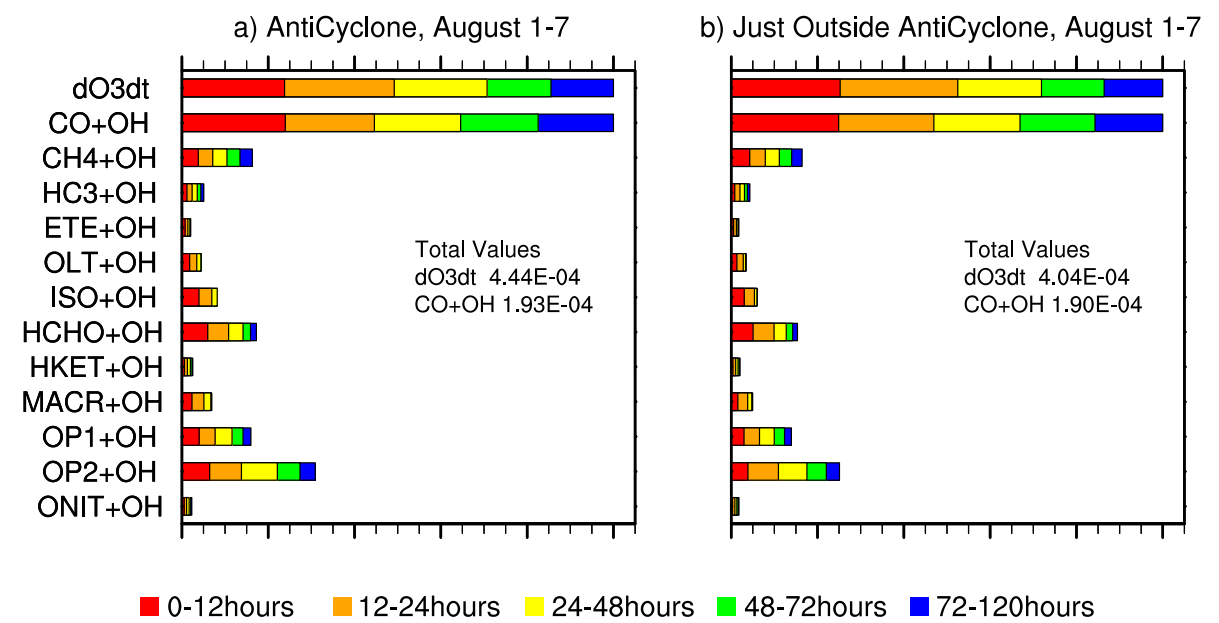

Fig. 14. The contribution of various VOC oxidation reactions to peroxy radical formation is shown as a function of the age of air for inside (left panel) and just outside (right panel) the UT Anticyclone. Each contribution is averaged in the upper troposphere (8-12 km altitude range) over one of the time periods described in the meteorology section of the paper. The $\mathrm{dO}_{3} \mathrm{~d} t$ and $\mathrm{CO}+\mathrm{OH}$ rates are normalized by their total value (listed in the panel) in the region and time period, while the other reaction rates are normalized by the $\mathrm{CO}+\mathrm{OH}$ total value in the region and time period. The horizontal area of the Anticyclone is defined as the region by $z>9730 \mathrm{~m}$ at $300 \mathrm{hPa}$. The horizontal area of the Just Outside Anticyclone region is defined as the region by $9730 \mathrm{~m}>z>9680 \mathrm{~m}$ at $300 \mathrm{hPa}$ and only includes grid points within $600 \mathrm{~km}$ of the Anticyclone.

likely were allowed to accumulate and chemically react to produce ozone. Second, the grid spacing of our WRF-Chem simulation (both horizontally and vertically) permits filamentary plumes to be resolved. These plumes are not resolved in the coarse-scale interpolation done by Cooper et al. (2007). The horizontal and vertical resolution used in our study can also explain differences with other regional modeling studies (Allen et al., 2010, 2012; Zhao et al., 2009).

\subsection{Ozone production}

The ozone chemical tendency per square kilometer (Fig. 13, right axis) has similar values in the two regions, peaking between 0.004 and $0.007 \mathrm{~kg} \mathrm{~km}^{-2}$. On average, the ozone chemical tendency is $8 \%$ greater within the anticyclone than just outside the anticyclone. During the 26-31 July and 17 August time periods, even greater ozone chemical tendencies $(17 \%$ and $10 \%$ increase, respectively) occurred within the anticyclone. Thus, when the anticyclone transitioned from the western to the eastern US more ozone was chemically produced within the anticyclone, which is consistent with the observed enhancement of ozone over the southeastern US (e.g., Cooper et al., 2007). In addition, these increases in ozone chemical tendency are in line with the results of Lawrence et al. (2003) who found a global effect of convection on $\mathrm{O}_{3}$ to be a $12 \%$ increase.

\section{3 $\mathrm{O}_{3}$ production based on age of air in each region}

To further understand the ozone production within and just outside the UT anticyclone, the model results for the 8-12 km altitude region are sampled based on the age of the air since it has left the boundary layer and based on the anticyclone region. The rates are calculated in the same manner as was done for the geographical region analysis, but are normalized by the number of grid points in each category to give a rate per volume result. Similar to the geographical regional analysis, the ozone chemical tendency and the $\mathrm{CO}+\mathrm{OH}$ reaction rate are normalized by their respective total values, as listed in the figure, for each region and meteorological time period. The other reaction rates of hydrocarbons with $\mathrm{OH}$ are normalized by the $\mathrm{CO}+\mathrm{OH}$ total rate to show the relative importance of each reaction.

The 1-7 August time period (Fig. 14) is used to illustrate the results. For both within and just outside the anticyclone, approximately $50 \%$ of the oxidation of $\mathrm{CO}$, methane, NMHCs and other VOCs happens within the first $24 \mathrm{~h}$ since the air was lofted from the boundary layer. When the anticyclone is located over the southeastern and southern US states (1-7 August), isoprene chemistry becomes important, especially in the anticyclone in which oxidation of isoprene, methacrolein, and organic peroxides are $40 \%, 40 \%$, and $20 \%$ greater, respectively, within the anticyclone than outside it. The oxidation of most of these hydrocarbons primarily occurs in air $<24 \mathrm{~h}$ old. However, organic peroxide and $\mathrm{CH}_{3} \mathrm{OOH}$ oxidation have nearly equal contributions from the different ages of air, suggesting that these peroxides contribute to peroxy radical production from both lofting of these species from the boundary layer and production from other hydrocarbon oxidation reactions in a low $\mathrm{NO}_{\mathrm{x}}$ environment. 
a) Stratosphere Tracer (\%)

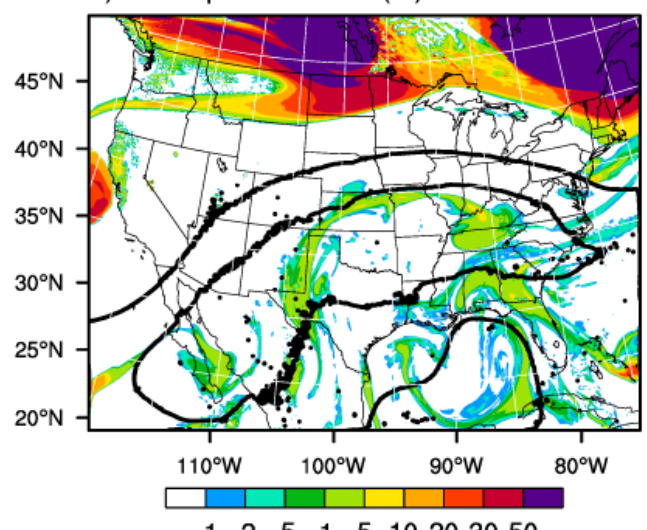

$\begin{array}{lllllllll}.1 & .2 & .5 & 1 & 5 & 10 & 20 & 30 & 50\end{array}$

b) Age of BL Tracer (hours)

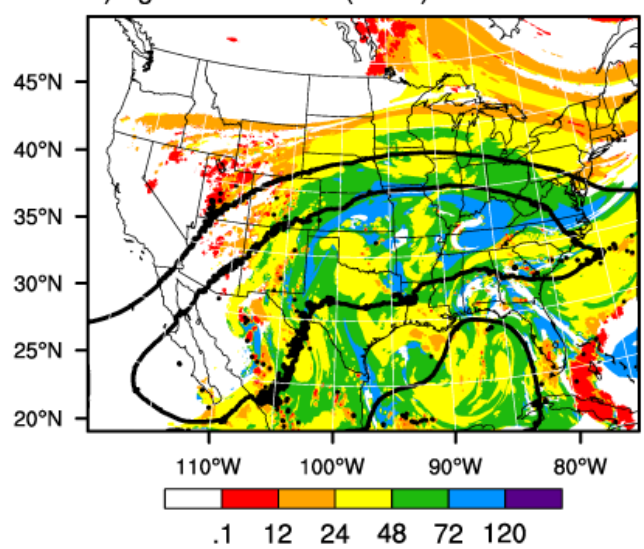

c) $\mathrm{O}_{3} \quad$ (ppbv)

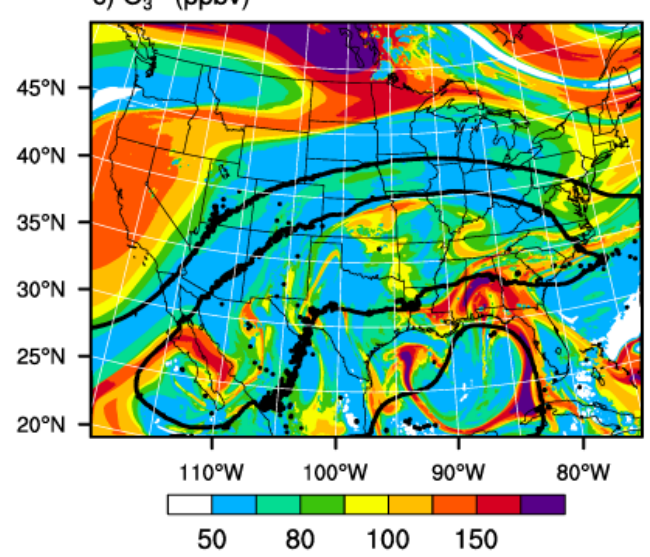

Fig. 15. WRF-Chem simulated (a) decaying stratosphere tracer (\%), (b) age of the boundary layer tracer (hours), and (c) $\mathrm{O}_{3}$ mixing ratio (ppbv) at $250 \mathrm{hPa}$ for 21:00 UTC 5 August 2006. Contour levels for $\mathrm{O}_{3}$ are $50,70,80,90,100,120,150$, and 200 ppbv. Overlaid is geopotential height at $300 \mathrm{hPa}$ for $z=9680 \mathrm{~m}$ and $9730 \mathrm{~m}$, which defines the anticyclone in the analysis.
In addition to the source of $\mathrm{O}_{3}$ from the chemistry, there is a source of $\mathrm{O}_{3}$ from the stratosphere that is concurrent with the convection, especially during the last 14 days of the simulation (Fig. 13). Much of the stratospheric air in the upper troposphere occurs in regions marked as 3-5 days since convective lofting. For example, the instantaneous results at 21:00 UTC on 5 August (Fig. 15) show stratospheric air at $250 \mathrm{hPa}$ within and along the edge of the anticyclone, as defined by the $300 \mathrm{hPa}$ geopotential height of $9730 \mathrm{~m}$. This same region has air that is more than 3 days old. One can also see recently lofted air often next to the older air. Plumes of $\mathrm{O}_{3}$ that are correlated with the stratosphere tracer contain mixing ratios of up to $200 \mathrm{ppbv}$ at $250 \mathrm{hPa}$. These plumes are in both the anticyclone and just outside the anticyclone. While these plumes are rather long, they are often quite narrow (100-200 km wide), which may be difficult to represent in simulations using coarser grid spacing. The high ozone mixing ratios originating from the stratosphere appear to be greater and more widespread than the $\mathrm{O}_{3}$ in UT convective outflow. For example, $\mathrm{O}_{3}$ is $\sim 75 \mathrm{ppbv}$ above Utah and Colorado (Fig. 15) where the age of the BL tracer is $<24 \mathrm{~h}$, while $\mathrm{O}_{3}$ is $\sim 120 \mathrm{ppbv}$ over the Kansas-Missouri border where the stratosphere tracer also exists. It is the combination of stratospheric air entraining into the anticyclone and in situ $\mathrm{O}_{3}$ chemical production that contributes to the production and maintenance of high $\mathrm{O}_{3}$ in the UT.

\section{Conclusions}

A high-resolution simulation of meteorology and chemistry was performed for the continental US and northern Mexico region to examine the contributions of convective transport in different geographic and meteorological regions to the upper troposphere composition and chemistry. The WRF-Chem results are evaluated with ECMWF ERA-Interim geopotential height and 2-m temperature, NWS radar reflectivity composite data, TES $\mathrm{CO}$ and $\mathrm{O}_{3}$ satellite retrievals, ozonesonde data, and MOZAIC aircraft vertical profiles. The evaluation points out that WRF-Chem reproduces the large-scale meteorology and more intense storms ( $>35 \mathrm{dBZ}$ reflectivity) well, but tends to overestimate weak convection $(<20 \mathrm{dBZ}$ reflectivity). The WRF-Chem model predicts upper troposphere $\mathrm{CO}$ and $\mathrm{O}_{3}$ to within $10-25 \%$ of measurements. However, the frequency of high $\mathrm{CO}$ in the upper troposphere is overpredicted by WRF-Chem suggesting too much convective lofting of boundary layer air.

An analysis of 23 simulated days is performed to understand the role of deep convection on the composition and chemistry of the upper troposphere. Analysis of different geographic regions (West Coast, Rocky Mountains, Central Plains, Midwest, and Gulf Coast) reveals that much of the convective transport occurs in the Rocky Mountains, while much of the ozone chemical production occurs in the upper troposphere over the Gulf Coast and Midwest regions 
where both $\mathrm{CO}$ and VOCs are abundant. In all regions most of the ozone chemical production occurs within $24 \mathrm{~h}$ since the air was lofted from the boundary layer. Besides $\mathrm{CO}$, organic peroxides (excluding $\mathrm{CH}_{3} \mathrm{OOH}$ ) produce $10-30 \%$ of the peroxy radicals, which potentially create $\mathrm{NO}_{2}$ and $\mathrm{O}_{3}$. This estimate is an upper bound of the contribution of organic peroxides to peroxy radical formation because of the underestimation of lightning flash rates and potentially lightning$\mathrm{NO}_{\mathrm{x}}$, which should reduce peroxide formation. Over the Gulf Coast region, in particular, biogenic VOCs (e.g. isoprene and methacrolein) are important UT ozone precursors.

Analysis of the anticyclone associated with the North American Monsoon and of the region just outside the anticyclone shows that there are fairly similar amounts of $\mathrm{O}_{3}$ in both regions. The $\mathrm{O}_{3}$ is a product of both stratospheric air (as indicated by a stratosphere tracer) and in situ $\mathrm{O}_{3}$ chemical production (as indicated by the chemistry diagnostic). When the anticyclone is over the southern US, there is up to $17 \%$ more in situ $\mathrm{O}_{3}$ production, 30-35\% more boundary layer air, and less stratospheric air within the anticyclone than just outside the anticyclone, which is consistent with the previous findings of Cooper et al. (2007). There are specific periods when stratospheric air resides in the anticyclone indicating that while BL air is being lofted stratospheric air is also being entrained into the UT. Examination of instantaneous model results shows both higher concentrations and spatially more widespread $\mathrm{O}_{3}$ co-located with the stratosphere tracer within the UT anticyclone than $\mathrm{O}_{3}$ co-located with $\mathrm{BL}$ air recently lofted to the UT. While both chemical and dynamical processes are enhancing the UT $\mathrm{O}_{3}$, ozone from the stratosphere appears to have the greater contribution to this enhancement. Previous studies (Cooper et al., 2007; Allen et al., 2010, 2012; and Zhao et al., 2009) attribute enhanced UT $\mathrm{O}_{3}$ more to the in situ chemical production of $\mathrm{O}_{3}$ with enhanced $\mathrm{NO}_{\mathrm{x}}$ from lightning than to the stratosphere. In addition to analyzing a slightly different time period (this study focused on mid-July to early August when the anticyclone was transitory, while the previous studies focused on August when the anticyclone was more stationary over the south central US), these previous studies differ from the current study primarily because of the grid spacing used in both the horizontal and vertical directions. The high resolution used in this study allows for the filaments of stratospheric air to exist in the upper troposphere. Field studies, such as the Deep Convective Clouds and Chemistry campaign, should provide more information on the composition and ozone production in the UT convective outflow regions and the filamentary nature of the UT, thereby putting more constraints on the UT chemistry.

These results provide some insight into the chemistry occurring in convective outflow regions, but inherent in the results are uncertainties in the chemistry mechanism parameterization, emissions inventory, and the prediction and representation of small-scale convective storms. Of particular concern is the chemistry parameterization that lumps reac- tive organic peroxides and organic aldehydes, because previous studies have found that $\mathrm{H}_{2} \mathrm{O}_{2}$ and $\mathrm{CH}_{3} \mathrm{OOH}$ are the dominant peroxides in the upper troposphere. Thus, chemical mechanisms must continue to be improved.

Acknowledgements. The work was partially supported by NASA grant NNX07AM47G. The National Center for Atmospheric Research is supported by the National Science Foundation. Part of this research was carried out at the Jet Propulsion Laboratory, California Institute of Technology, under a contract with the National Aeronautics and Space Administration. The authors appreciate the computer time made available for this project and for the assistance of the supercomputer engineers from the CISL at NCAR and from the NASA Ames computing group. Stuart McKeen (NOAA/ESRL) is thanked for providing the $4 \mathrm{~km}$ gridded anthropogenic emissions from the EPA inventory. Christine Wiedinmyer and Louisa Emmons provided biogenic VOC and fire emissions data and CAM-Chem results for the boundary conditions. The Global Monitoring Division of NOAA/ESRL is kindly acknowledged for the ozonesonde data. We also acknowledge the European Commission and its partner institutions in Germany, France and the UK for the support to the MOZAIC project. We thank Anne Boynard, Christine Wiedinmyer, and the three anonymous reviewers for helpful comments on the manuscript. The WRF-Chem simulation performed on the bluefire machine (an IBM clustered Symmetric MultiProcessing (SMP) system based on the Power6 chip) at NCAR used 728 processors. One day of integration took $\sim 20 \mathrm{~h}$ to compute. The hourly output files are $39 \mathrm{~Gb}$ in size and are available for scientific investigations upon request.

Edited by: R. Cohen

\section{References}

Ackermann, I. J., Hass, H., Memmesheimer, M., Ebel, A., Binkowski, F. S., and Shankar, U.: Modal aerosol dynamics model for Europe: Development and first applications, Atmos. Environ., 32, 2981-2999, 1998.

Allen, D., Pickering, K., Duncan, B., and Damon, M: Impact of lightning NO emissions on North American photochemistry as determined using the Global Modeling Initiative (GMI) model, J. Geophys. Res., 115, D22301, doi:10.1029/2010JD014062, 2010.

Allen, D. J., Pickering, K. E., Pinder, R. W., Henderson, B. H., Appel, K. W., and Prados, A.: Impact of lightning-NO on eastern United States photochemistry during the summer of 2006 as determined using the CMAQ model, Atmos. Chem. Phys., 12, 1737-1758, doi:10.5194/acp-12-1737-2012, 2012.

Baughcum, S., Tritz, T., Henderson, S., and Pickett, D.: Scheduled Civil Aircraft Emission Inventories for 1992: Database Development and Analysis, NASA Contractor Report 4700, available at: http://ntrs.nasa.gov/archive/nasa/casi.ntrs.nasa.gov/ 199600384451996060751.pdf, (last access: August 2007), 1996.

Baughcum, S., Henderson, S., and Sutkus, D.: Scheduled Civil Aircraft Emission Inventories Projected for 2015: Database Development and Analysis, NASA/CR-1998-207638, available at: http://ntrs.nasa.gov/archive/nasa/casi.ntrs.nasa.gov/ 199800552001998120133.pdf, (last access: August 2007), 1998. 
Binkowski, F. S. and Shankar, U.: The regional particulate matter model, 1 . Model description and preliminary results, J. Geophys. Res., 100, 26191-26209, 1995.

Boccippio, D. J., Cummins, K. L. Christian, H. J., and Goodman, S. J.: Combined satellite- and surface-based estimation of the intracloud-cloud-to-ground lightning ratio over the continental United States, Mon. Weather Rev., 129, 108-122, 2001.

Cavallo, S. M., Dudhia, J., and Snyder, C.: A multilayer upperboundary condition for longwave radiative flux to correct temperature biases in a mesoscale model, Mon. Weather Rev., 139, 1952-1959, 2011.

Chapman, E. G., Gustafson Jr., W. I., Easter, R. C., Barnard, J. C., Ghan, S. J., Pekour, M. S., and Fast, J. D.: Coupling aerosolcloud-radiative processes in the WRF-Chem model: Investigating the radiative impact of elevated point sources, Atmos. Chem. Phys., 9, 945-964, doi:10.5194/acp-9-945-2009, 2009.

Chatfield, R. B. and Crutzen, P. J.: Sulfur dioxide in remote oceanic air: Cloud transport of reactive precursors, J. Geophys. Res., 89, 7111-7132, 1984.

Chen, F. and Dudhia, J.: Coupling an advanced land-surface/ hydrology model with the Penn State/NCAR MM5 modeling system, Part I: Model description and implementation. Mon. Weather Rev., 129, 569-585, 2001.

Choi, Y., Kim, J., Eldering, A., Osterman, G., Yung, Y. L., Gu, Y., and Liou, K. N.: Lightning and anthropogenic $\mathrm{NO}_{\mathrm{X}}$ sources over the United States and the western North Atlantic Ocean: Impact on OLR and radiative effects, Geophys. Res. Lett., 36, L17806, doi:10.1029/2009GL039381, 2009.

Chou M.-D. and Suarez, M. J.: An efficient thermal infrared radiation parameterization for use in general circulation models, NASA Tech. Memo. 104606, 3, 85 pp. 1994.

Cooper, O. R., Trainer, M., Thompson, A. M., Witte, J. C., Oltmans, S. J., Morris, G., Pickering, K. E., Crawford, J. H., Chen, G., Cohen, R. C., Bertram, T. H., Wooldridge, P., Perring, A., Brune, W. H., Merrill, J., Moody, J. L., Tarasick, D., Nédélec, P., Forbes, G., Newchurch, M. J., Schmidlin, F. J., Johnson, B. J., Turquety, S., Baughcum, S. L., Ren, X., Fehsenfeld, F. C., Meagher, J. F., Spichtinger, N., Brown, C. C., McKeen, S. A., McDermid, I. S., and Leblanc, T.: Large upper tropospheric ozone enhancements above midlatitude North America during summer: In situ evidence from the IONS and MOZAIC ozone measurement network, J. Geophys. Res., 111, D24S05, doi:10.1029/2006JD007306, 2006.

Cooper, O. R., Trainer, M., Thompson, A. M., Oltmans, S. J., Tarasick, D., Witte, J. C., Stohl, A., Eckhardt, S., Lelieveld, J., Newchurch, M. J., Johnson, B. J., Portmann, R. W., Kalnajs, L., Dubey, M. K., Leblanc, T., McDermid, I. S., Forbes, G., Wolfe, D., Carey-Smith, T., Morris, G. A., Lefer, B., Rappenglück, B., Joseph, E., Schmidlin, F. J., Meagher, J. F., Fehsenfeld, F. C., Keating, T. J., Van Curen, R. A., and Minschwaner, K.: Evidence for a recurring eastern North America upper tropospheric ozone maximum during summer, J. Geophys. Res., 112, D23304, doi:10.1029/2007JD008710, 2007.

Cooper, O. R., Eckhardt, S., Crawford, J. H., Brown, C. C., Cohen, R. C., Bertram, T. H., Wooldridge, P., Perring, A., Brune, W. H., Ren, X., Brunner, D., and Baughcum, S. L.: Summertime buildup and decay of lightning $\mathrm{NO}_{\mathrm{x}}$ and aged thunderstorm outflow above North America, J. Geophys. Res., 114, D01101, doi:10.1029/2008JD010293, 2009.
DeCaria, A. J., Pickering, K. E., Stenchikov, G. L., and Ott, L. E.: Lightning-generated $\mathrm{NO}_{\mathrm{x}}$ and its impact on tropospheric ozone production: A three-dimensional modeling study of a Stratosphere-Troposphere Experiment: Radiation, Aerosols and Ozone (STERAO-A) thunderstorm, J. Geophys. Res., 110, D14303, doi:10.1029/2004JD005556, 2005.

Dickerson, R. R., Huffman, G. J., Luke, W. T., Nunnermacker, L. J., Pickering, K. E., Leslie, A. C. D., Lindsey, C. G., Slinn, W. G. N., Kelly, T. J., Daum, P. H., Delany, A. C., Greenberg, J. P., Zimmerman, P. R., Boatman, J. F., Ray, J. D., and Stedman, D. H.: Thunderstorms: An important mechanism in the transport of air pollutants, Science, 235, 460-465, 1987.

Easter R. C., Ghan, S. J., Zhang, Y., Saylor, R. D., Chapman, E. G., Laulainen, N. S., Abdul-Razzak, H., Leung, L. R., Bian, X., and Zaveri, R. A.: MIRAGE: Model description and evaluation of aerosols and trace gases, J. Geophys. Res., 109, D20210, doi:10.1029/2004JD004571, 2004.

Emmons, L. K., Hess, P. G., Lamarque, J.-F., and Pfister, G. G.: Tagged ozone mechanism for MOZART-4, CAM-chem, and other chemical transport models, Geosci. Model Dev. Discuss., 5, 1949-1985, doi:10.5194/gmdd-5-1949-2012, 2012.

Fast J. D., Gustafson Jr., W. I., Easter, R. C., Zaveri, R. A., Barnard, J. C., Chapman, E. G., and Grell, G. A.: Evolution of ozone, particulates, and aerosol direct forcing in an urban area using a new fully-coupled meteorology, chemistry, and aerosol model, J. Geophys. Res., 111, D21305, doi:10.1029/2005JD006721, 2006.

Fast, J., Aiken, A. C., Allan, J., Alexander, L., Campos, T., Canagaratna, M. R., Chapman, E., DeCarlo, P. F., de Foy, B., Gaffney, J., de Gouw, J., Doran, J. C., Emmons, L., Hodzic, A., Herndon, S. C., Huey, G., Jayne, J. T., Jimenez, J. L., Kleinman, L., Kuster, W., Marley, N., Russell, L., Ochoa, C., Onasch, T. B., Pekour, M., Song, C., Ulbrich, I. M., Warneke, C., Welsh-Bon, D., Wiedinmyer, C., Worsnop, D. R., Yu, X.-Y., and Zaveri, R.: Evaluating simulated primary anthropogenic and biomass burning organic aerosols during MILAGRO: implications for assessing treatments of secondary organic aerosols, Atmos. Chem. Phys., 9, 6191-6215, doi:10.5194/acp-9-6191-2009, 2009.

Freitas, S. R., Longo, K. M., Diasb, M. A. F. S., Diasb, P. L. S., Chatfield, R., Prins, E., Artaxo, P., Grell, G. A., and Recuero, F. S.: Monitoring the transport of biomass burning emissions in South America, Environ. Fluid Mech., 5, 135-167, doi:10.1007/s10652-005-0243-7, 2005.

Freitas, S. R., Longo, K. M., Alonso, M. F., Pirre, M., Marecal, V., Grell, G., Stockler, R., Mello, R. F., and Sánchez Gácita, M.: PREP-CHEM-SRC - 1.0: a preprocessor of trace gas and aerosol emission fields for regional and global atmospheric chemistry models, Geosci. Model Dev., 4, 419-433, doi:10.5194/gmd-4419-2011, 2011.

Grell, G. A. and Devenyi, D.: A generalized approach to parameterizing convection combining ensemble and data assimilation techniques, Geophys. Res. Lett., 29, 1693, doi:10.1029/2002GL015311, 2002.

Grell G. A., Peckham, S. E., Schmitz, R., McKeen, S. A., Frost, G., Skamarock, W. C., and Eder, B.: Fully coupled "online" chemistry in the WRF model, Atmos. Environ., 39, 6957-6976, 2005.

Guenther, A., Karl, T., Harley, P., Wiedinmyer, C., Palmer, P. I., and Geron, C.: Estimates of global terrestrial isoprene emissions using MEGAN (Model of Emissions of Gases and Aerosols from Nature), Atmos. Chem. Phys., 6, 3181-3210, doi:10.5194/acp-6- 
3181-2006, 2006.

Hodzic, A., Jimenez, J. L., Madronich, S., Canagaratna, M. R., DeCarlo, P. F., Kleinman, L., and Fast, J.: Modeling organic aerosols in a megacity: potential contribution of semi-volatile and intermediate volatility primary organic compounds to secondary organic aerosol formation, Atmos. Chem. Phys., 10, 5491-5514, doi:10.5194/acp-10-5491-2010, 2010.

Janjic, Z. I.: Nonsingular implementation of the Mellor-Yamada Level 2.5 scheme in the NCEP meso model, NCEP Office Note, No. 437, 61 pp., 2002.

Jourdain, L., Kulawik, S. S., Worden, H. M., Pickering, K. E., Worden, J., and Thompson, A. M.: Lightning $\mathrm{NO}_{\mathrm{x}}$ emissions over the USA constrained by TES ozone observations and the GEOS-Chem model, Atmos. Chem. Phys., 10, 107-119, doi:10.5194/acp-10-107-2010, 2010.

Lamarque, J.-F., Emmons, L. K., Hess, P. G., Kinnison, D. E., Tilmes, S., Vitt, F., Heald, C. L., Holland, E. A., Lauritzen, P. H., Neu, J., Orlando, J. J., Rasch, P. J., and Tyndall, G. K.: CAM-chem: description and evaluation of interactive atmospheric chemistry in the Community Earth System Model, Geosci. Model Dev., 5, 369-411, doi:10.5194/gmd-5-369-2012, 2012.

Lawrence, M. G., von Kuhlmann, R., Salzmann, M., and Rasch, P. J.: The balance of effects of deep convective mixing on tropospheric ozone, Geophys. Res. Lett., 30, 1940, doi:10.1029/2003GL017644, 2003.

Lelieveld, J. and Crutzen, P. J.: Role of deep cloud convection in the ozone budget of the troposphere, Science, 264, 1759-1761, 1994.

Li, Q., Jacob, D. J., Park, R., Wang, Y., Heald, C. L., Hudman, R., Yantosca, R. M., Martin, R. V., and Evans, M.: North American pollution outflow and the trapping of convectively lifted pollution by upper-level anticyclone, J. Geophys. Res., 110, D10301, doi:10.1029/2004JD005039, 2005.

Lin, Y.-L., Farley, R. D., and Orville, H. D.: Bulk parameterization of the snow field in a cloud model, J. Clim. Appl. Meteorol., 22, 1065-1092, 1983.

Marenco, A., Thouret, V., Nedelec, P., Smit, H., Helten, M., Kley, D., Karcher, F., Simon, P., Law, K., Pyle, J., Poschmann, G., Von Wrede, R., Hume, C., and Cook, T.: Measurement of ozone and water vapor by Airbus in-service aircraft: The MOZAIC airborne program, An overview, J. Geophys. Res., 103, 25631-25642, doi:10.1029/98JD00977, 1998.

Mlawer, E. J., Taubman, S. J., Brown, P. D., Iacono, M. J., and Clough, S. A.: Radiative transfer for inhomogeneous atmosphere: RRTM, a validated correlated-k model for the longwave, J. Geophys. Res., 102, 16663-16682, 1997.

Mortlock, A. and Alstyne, R. V.: Military, Charter, Unreported Domestic Traffic and General Aviation: 1976, 1984, 1992, and 2015 Emission Scenarios, NASA CR-1998-207639, available at: http://ntrs.nasa.gov/archive/nasa/casi.ntrs.nasa.gov/ 199800473461998120131.pdf (last access: August 2007), 1998.

Park, R. J., Pickering, K. E., Allen, D. J., Stenchikov, G. L., and Fox-Rabinovitz, M. S.: Global simulation of tropospheric ozone using the University of Maryland Chemical Transport Model (UMD-CTM): 2. Regional transport and chemistry over the central United States using a stretched grid, J. Geophys. Res., 109, D09303, doi:10.1029/2003JD004269, 2004.
Price, C. and Rind, D.: A Simple Lightning Parameterization for Calculating Global Lightning Distributions, J. Geophys. Res., 97, 9919-9933, doi:10.1029/92JD00719, 1992.

Roelofs, G.-J. and Lelieveld, J.: Model study of the influence of cross- tropopause $\mathrm{O}_{3}$ transports on tropospheric $\mathrm{O}_{3}$ levels, Tellus B, 49, 38-55, 1997.

Sandu, A. and Sander, R.: Technical note: Simulating chemical systems in Fortran90 and Matlab with the Kinetic PreProcessor KPP-2.1, Atmos. Chem. Phys., 6, 187-195, doi:10.5194/acp-6187-2006, 2006.

Saxena, P., Hudeschewskyj, A. B., Seigneur, C., and Seinfeld, J. H.: A comparative study of equilibrium approaches to the chemical characterization of secondary aerosols, Atmos. Environ., 20, 1471-1483, 1986.

Seifert, A. and Weisman, M.: A comparison of bulk microphysical schemes for cloud resolving numerical weather prediction, WRF Users' Workshop, http://www.mmm.ucar.edu/wrf/users/ workshops/WS2005/abstracts/Session6/2-Seifert.pdf, 2005.

Shaw, W., Allwine, K. J., Fritz, B. G., Rutz, F. C., Rishel, J. P., and Chapman, E. G.: An evaluation of the wind erosion module in DUSTRAN, Atmos. Environ., 42, 1907-1921, 2008.

Snow, J. A., Heikes, B. G., Shen, H., O'Sullivan, D. W., Fried, A., and Walega, J.: Hydrogen peroxide, methyl hydroperoxide, and formaldehyde over North America and the North Atlantic, J. Geophys. Res., 112, D12S07, doi:10.1029/2006JD007746, 2007.

Skamarock, W. C., Klemp, J. B., Dudhia, J., Gill, D. O., Barker, D. M., Duda, M. G., Huang, X.-Y., Wang, W., and Powers, J. G: A description of the advanced research WRF version 3, NCAR Technical Note, NCAR/TN-475+STR, 125 pp., 2008.

Stephens, S., Madronich, S., Wu, F., Olson, J. B., Ramos, R., Retama, A., and Muñoz, R.: Weekly patterns of México City's surface concentrations of $\mathrm{CO}, \mathrm{NO}_{\mathrm{x}}, \mathrm{PM}_{10}$ and $\mathrm{O}_{3}$ during 19862007, Atmos. Chem. Phys., 8, 5313-5325, doi:10.5194/acp-85313-2008, 2008.

Stockwell, W. R., Kirchner, F., Kuhn, M., and Seefeld, S.: A new mechanism for regional atmospheric chemistry modeling, J. Geophys. Res., 102, 25847-25879, 1997.

Sutkus, D., Baughcum, S., and DuBois, D.: Scheduled Civil Aircraft Emission Inventories for 1999: Database Development and Analysis, NASA/CR-2001-211216, available at: http://hdl.handle.net/ 2060/20020012699 (last access: August 2007), 2001.

Thompson, A. M., Yorks, J. E., Miller, S. K., Witte, J. C., Dougherty, K. M., Morris, G. A., Baumgardner, D., Ladino, L., and Rappenglück, B.: Tropospheric ozone sources and wave activity over Mexico City and Houston during MILAGRO/Intercontinental Transport Experiment (INTEX-B) Ozonesonde Network Study, 2006 (IONS-06), Atmos. Chem. Phys., 8, 5113-5125, doi:10.5194/acp-8-5113-2008,

Tie, X., Madronich, S., Walters, S., Zhang, R., Rasch, P., and Collins, W.: Effect of clouds on photolysis and oxidants in the troposphere, J. Geophys. Res., 108, 4642, doi:10.1029/2003JD003659, 2003.

Wang, H., Skamarock, W. C., and Feingold, G.: Evaluation of scalar advection schemes in the advanced research WRF model using large-eddy simulations of aerosol-cloud interaction, Mon. Weather Rev., 137, 2547-2558, doi:10.1175/2009MWR2820.1, 2009.

Wang, Y., Jacob, D. J., and Logan, J. A.: Global simulation of tropospheric O3-NOx-hydrocarbon chemistry, 3, Origin of tropo- 
spheric ozone and effects of nonmethane hydrocarbons, J. Geophys. Res., 103, 10757-10767, 1998.

Wesely, M.: Parameterization of surface resistances to gaseous dry deposition in regional-scale numerical models, Atmos. Environ., 23, 1293-1304, 1989.

Wiedinmyer, C., Quayle, B. Geron, C. Belote, A. McKenzie, D. Zhang, X., O'Neill, S., and Klos Wynne, K.: Estimating emissions from fires in North America for air quality modeling, Atmos. Environ., 40, 3419-3432, 2006.

Wong, J., Barth, M. C., and Noone, D.: Evaluating a lightning parameterization based on cloud-top height for mesoscale numerical model simulations, Geosci. Model Dev. Discuss., 5, 3493 3531, doi:10.5194/gmdd-5-3493-2012, 2012.
Worden J. R., Bowman, K. W., and Jones, D. B.: Two-dimensional characterization of atmospheric profile retrievals from limb sounding observations, J. Quant. Spectrosc. Ra., 86, 45-71, 2004.

Zhang, R. Y., Tie, X. X., and Bond, D. W.: Impacts of anthropogenic and natural NOx sources over the US on tropospheric chemistry, P. Natl. Acad. Sci. USA, 100, 1505-1509, doi:10.1073/pnas.252763799, 2003.

Zhao, C., Wang, Y., Choi, Y., and Zeng, T.: Summertime impact of convective transport and lightning $\mathrm{NO}_{\mathrm{x}}$ production over North America: modeling dependence on meteorological simulations, Atmos. Chem. Phys., 9, 4315-4327, doi:10.5194/acp-9-43152009, 2009. 